

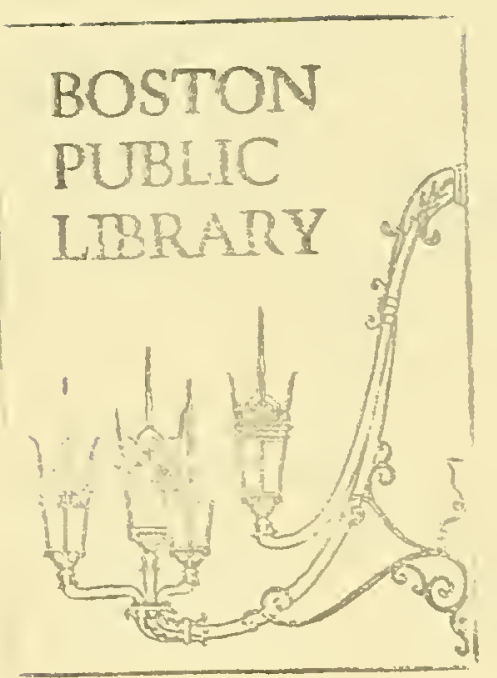


Digitized by the Internet Archive in 2012 with funding from Boston Public Library 



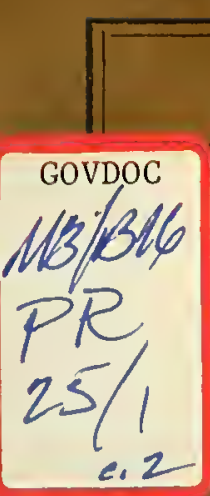

\section{CITY OF BOSTON}

\section{PARK DEPARTMENT}

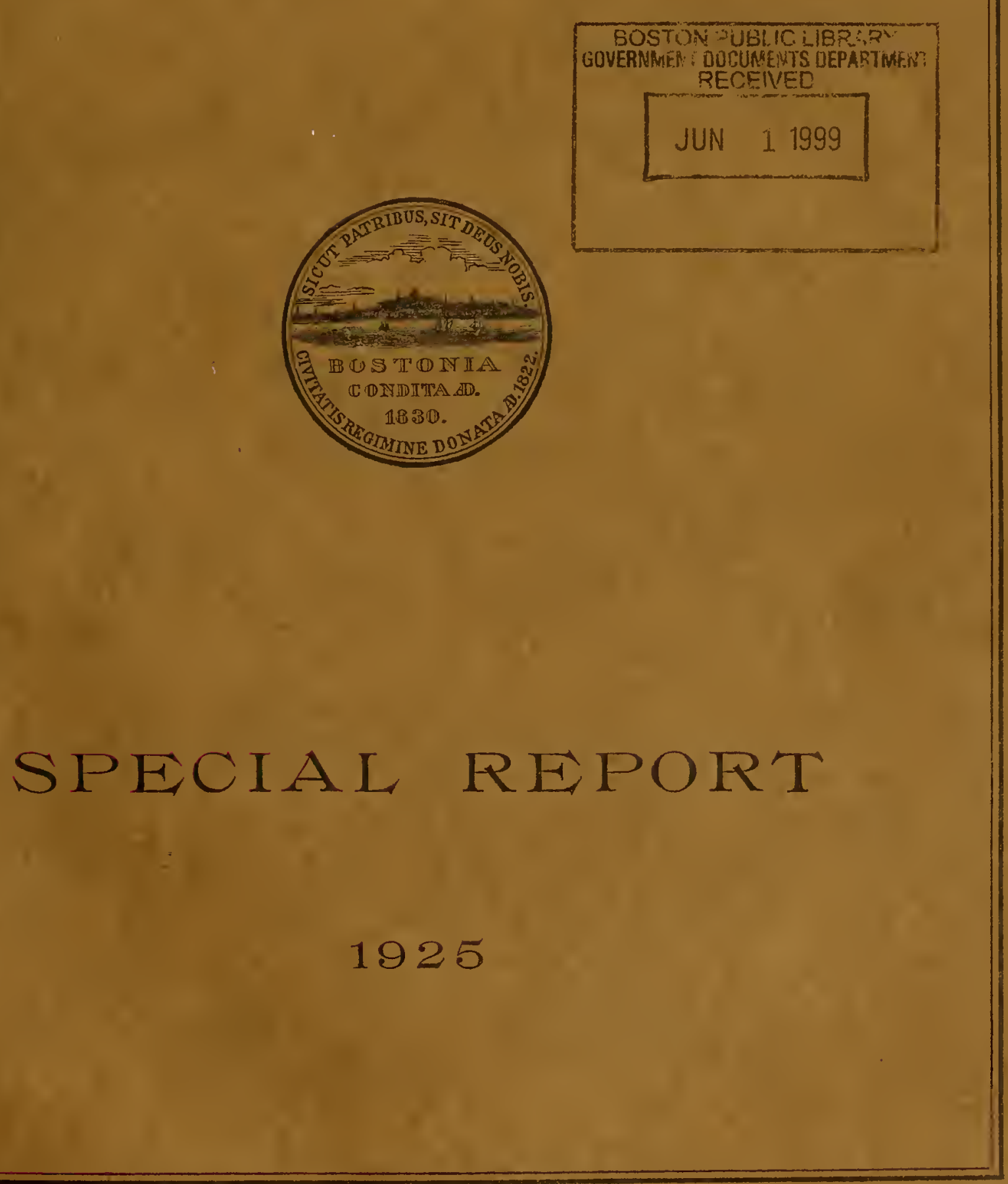





\section{CITY OF BOSTON}

\section{PARK DEPARTMENT}

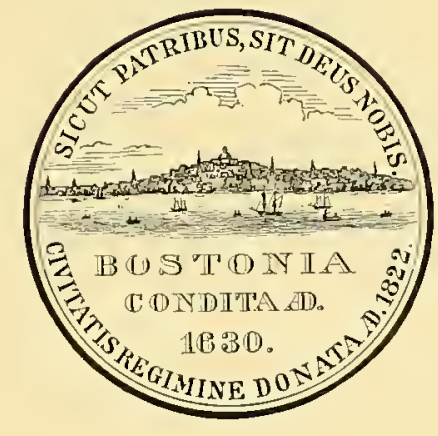

SPECIAL REPORT

1925 
Hon. James M. Curley,

Boston, December I, 1924 .

Mayor of the City of Boston:

Dear Sir, - The Park Department submits the following report, which reviews the relation of the Park System to recent park developments. The report also describes important plans which are now under construction or which are to be carried out in the near future in the Fens, at the Zoo, at Castle Island, in the newer playgrounds, and at Columbus Park and elsewhere. Inquiries are constantly made of this Department regarding the future development proposed for the open spaces of the City, and the parks and playgrounds included in this report have been the subjects of special public interest. This review of the plans and the purposes of the Department will assist in giving desired information in convenient form, and will also make a useful permanent record for future reference.

The Department is making good progress with a special report on the future development of the Park and Playground System of the City. This material is being studied with the growth of the industrial areas and the residence areas, in order to make an intelligent forecast of the probable needs of the next quarter to half a century. Further reference to this work is given in the appended report.

Respectfully submitted,

JAMES B. SheA, Chairman.

Charles A. Coolidge, Commissioner.

Myron P. Lewis, Commissioner.

Willian P. Long, Deputy Commissioner.

Daniel J. Byrne, Secretary and Chief Clerk.

Arthur A. Shurtleff, Landscape Architect. 


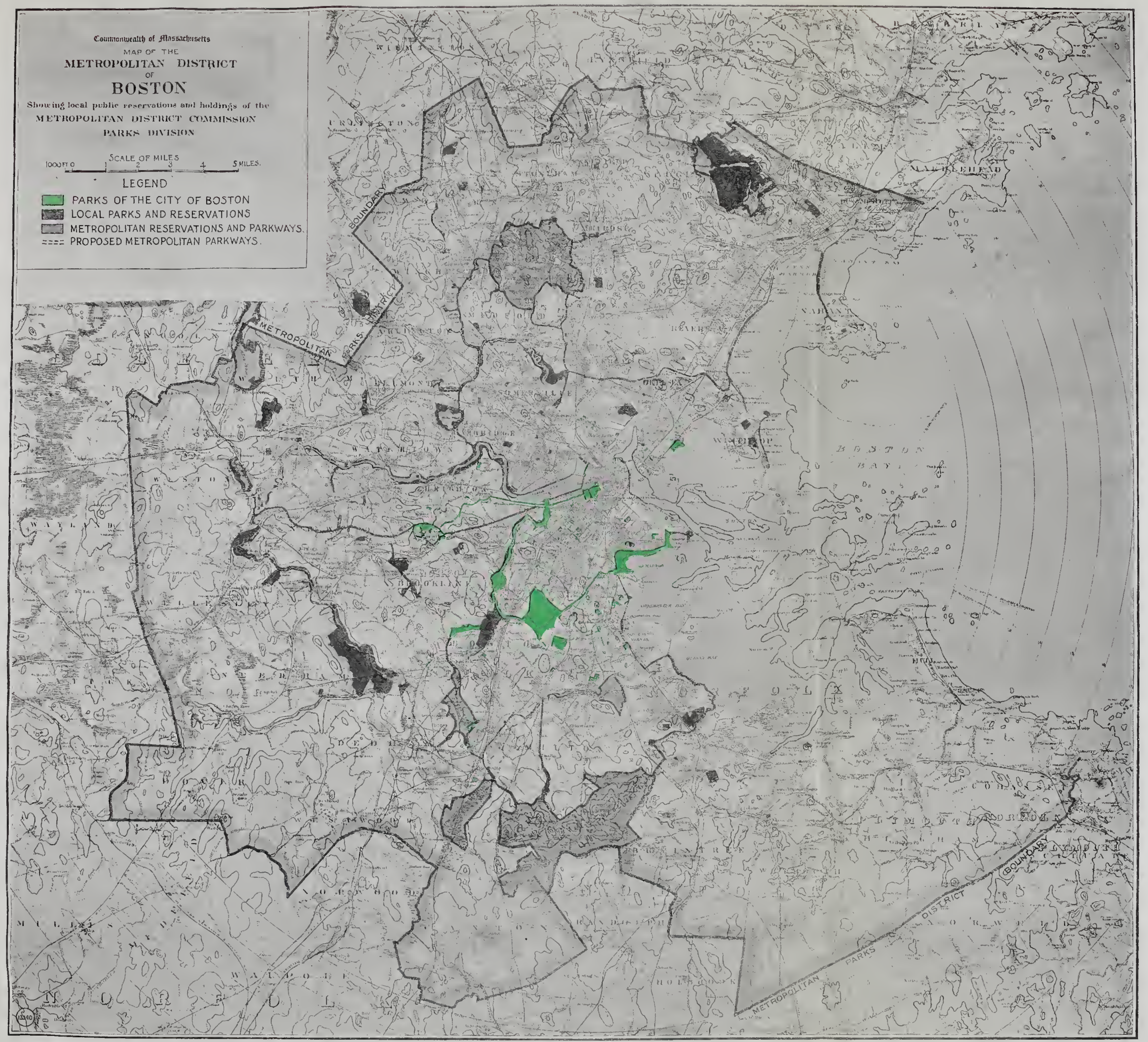

PLATE I.-MAP OF METROPOLITAN DISTRICI SHOWING BOSTON PARK SYSTEM IN RELATION TO OTHER PARKS AND PUBLIC OPEN SPACES. 


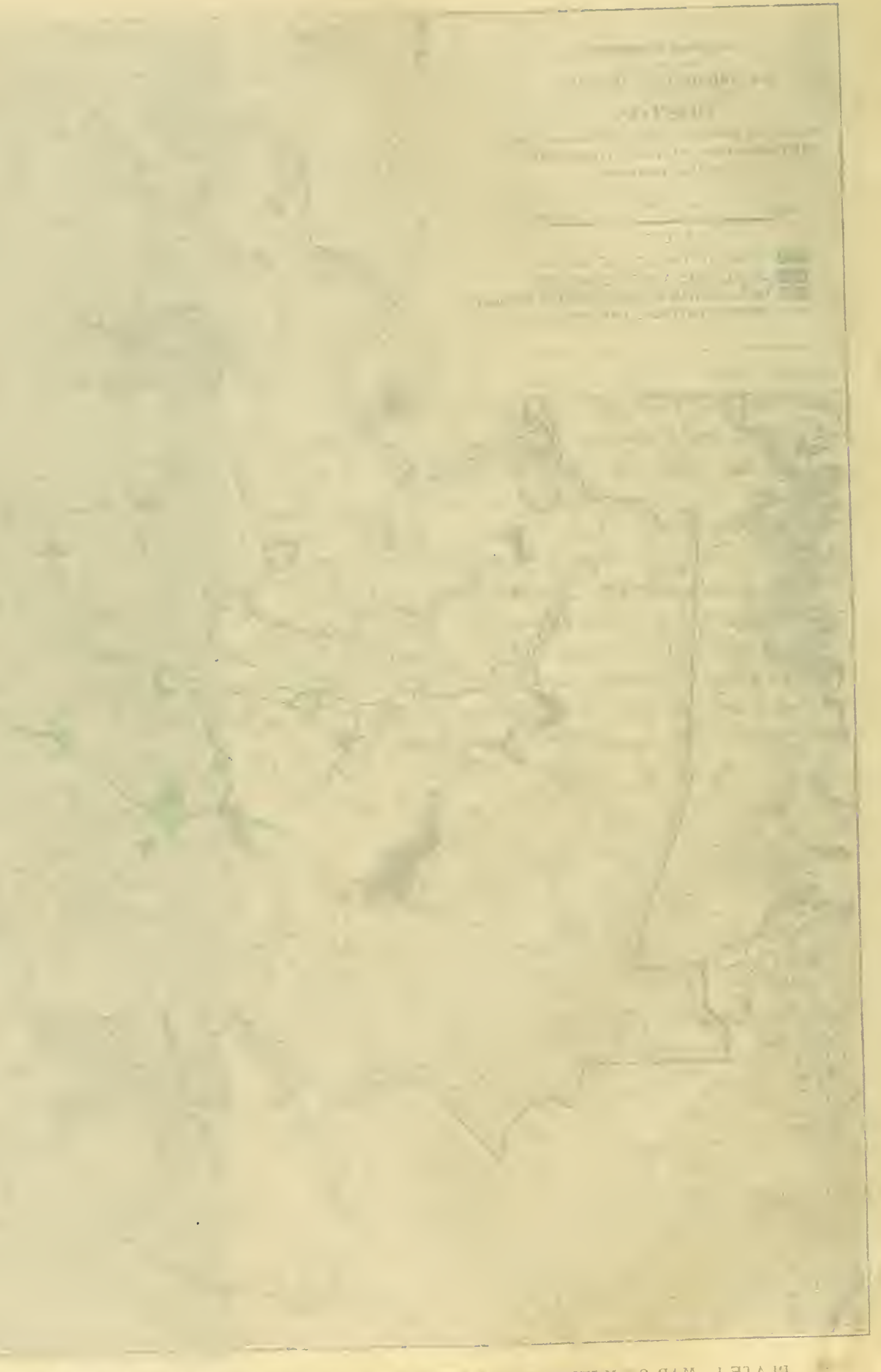

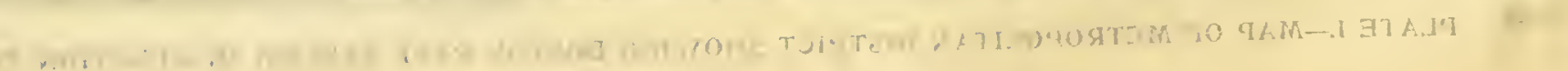


THE BOSTON PARK SYS'TEM.

The Boston Parks descrve the term of "System," first because they are physically connceted by an unbroken string of wide and attractive connceting parkways which lead from the Common at one cxtremity to City Point at the other terminus; sccond, the term is appropriate because thesc open spaces are laid out in a single style without conspictous breaks of design which would tend to divide the string into scctions of different typc; third, the local parks and playgrounds which are by neccssity detached from this string are distributed methodically to provide, as far as possible, equal recreation opportunitics in the outlying sections of the City.

Though this system may be complete today, it cannot remain so in the future without the constant acquisition of new park and playground areas or the improvement of old areas. The constant growth of the City makes this growth of the System necessary. This is not a theory upon which the City might be urged to act, but it is a fact upon which the City is constantly acting, and with special energy at the present day. There never was a time when new playgrounds were being more rapidly acquired and old playgrounds more generally enlarged and improved in their facilities than at the present time.

The parks of Boston are rendered still more perfect as a System and more useful individually through their relation to the outer ring of Metropolitan Parks and parkways which were developed after the Boston Parks were established. Each system is bccoming yearly more essential to the other. The map of the Boston and the Metropolitan Parks (Platc II) shows the position and size of each of these groups of parks. The map also indicates the location of the small local parks of the surrounding cities and towns of the district. The question at once arises, have these recreative facilities reached a point of development in which one group is duplicating the work of other groups? A general examination of the actual use made of these parks on Sundays and holidays, as well as on week days, indicates that they are all in intensive use. Many of them, like the bathing beaches and the ball field areas, are unable to acconmodate the throngs which seek them. There are no idle parks or playgrounds. In the winter season, it is true, greater use might be made of the wooded reservations and the larger country parks by snowshoers, trampers and "nature study" parties. This is a problem of education. In the summer season, however, the call to the parks is natural and constant. 'The present need is to bring the parlis nearer to the homes by creating more recreation areas in the residcnce districts. The doorsteps and the streets will continue always to serve as play spaces on certain days, at certain hours, and at certain pcriods in childhood and in old age, but the playground and the park will be a public neccssity always.

Transportation will probably never provide such rapid and such cheap transit that the families of one neighborhood will go by preference to distant neighborhoods for playgrounds. Consequently there appears to be no immediate danger of duplication of local playgrounds. With regard to the large country parks which should be spaced widely, a duplication might occur if they were placed near together, but at present there is no chance that such a liberal supply of these desirable open spaces could be afforded. If 
our climate were more bitter and the waters of ou1 shores very eold, we might soun possess too many bathing beaches in a eombination of the Boston and the Metropolitan Systems, but with our present elimate and with our population of enthusiastie bathers, the hot weather erowds overtax all the publie beaehes, and trespass upon the private beaches from Plymouth to Portland. In the ease of speeial reereative features like zoologieal parks, special eolleetions of plants or flowers, great publie stadiums, duplieation may be possible in the future, but at present the opportunities for speeial study or amusement afforded by these examples are still short of the eapaeity of Boston and the distriet to enjoy.

The Department, at the request of his Honor Mayor Curley, is now making a detailed study of the future development of the loeal parks and playgrounds of Boston. This study will indieate the distriets in whieh additional faeilities of this kind are now needed, or in whieh they will be needed in the future if the growth of the City eontinues at the present rate. The study will also eonsider in greater detail the relation of all the reereative faeilities of the distriet to the population of the City.

The relations between the Park Department and the City of Boston Planning Board have been very helpful. In determining the loeations for future playgrounds, the help of the Planning Board has been especially important. Evidently playgrounds and other reereation areas should be plaeed where they will not interfere with the future loeal street extensions or with main thoroughfares. Similarly it has been possible with a degree of eonfidenee to seeure the abandonment of streets whieh have heretofore separated pareels of playground area and thus unite them in a single traet, as in the instances of the Christopher Gibson and John A. Doherty Playgrounds. 


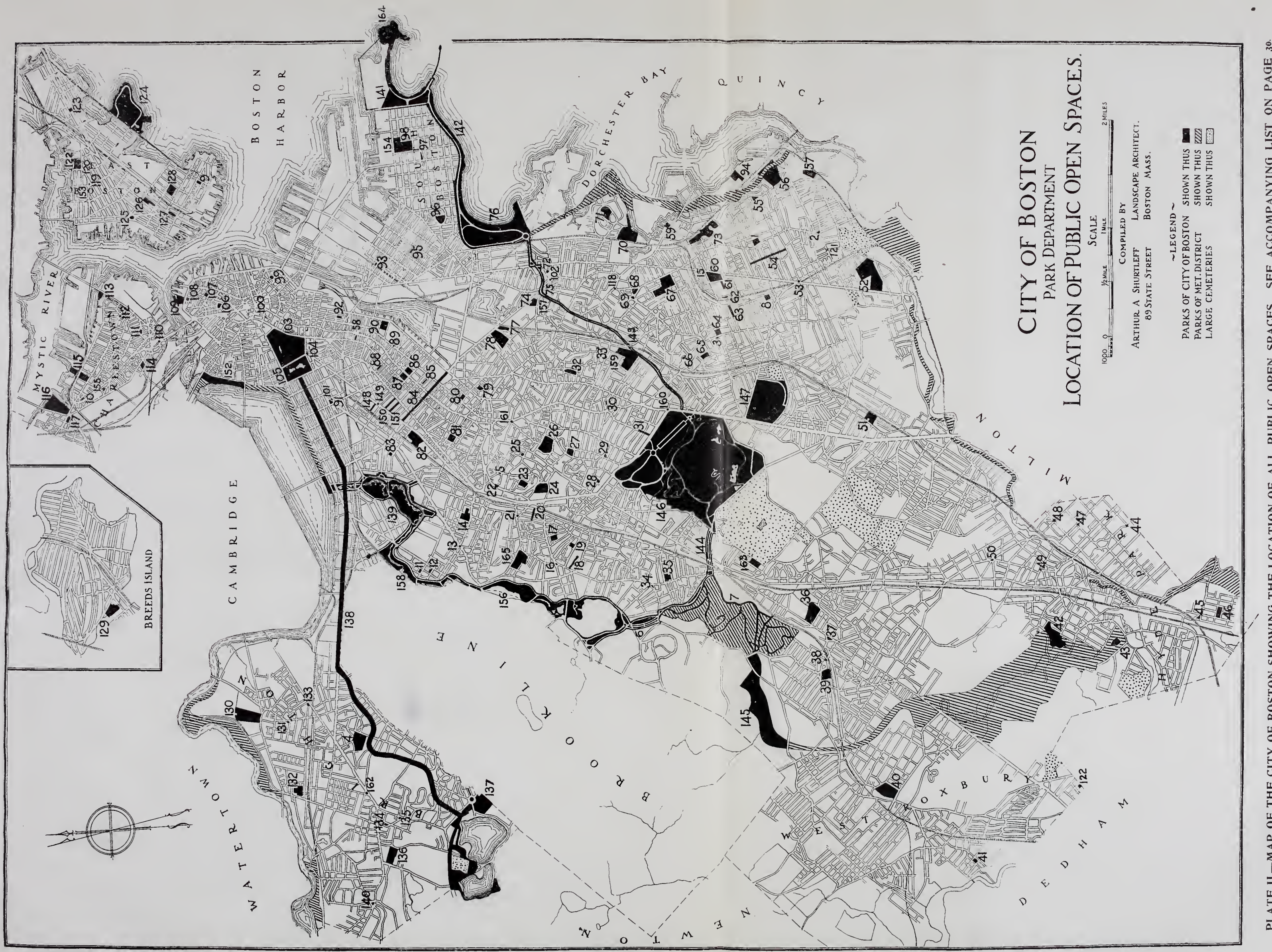




\section{BOS'TON COMMON.}

The program of replanting the Common with vigorous young trees set out in large tree pockets or in large continuous loam beds, as fast as individual decrepit trees die, is showing satisfactory results. Along the Beacon Strect Mall, and along the malls of Park Strect and Charles Street, the young trees are now large enough to indicate the good effeet which may be expected of them during the next few years of growth. At the music court of the Parkman Memorial, in general along the path system of the Common as a whole, and at the Frog Pond, all the newly planted trees are thriving. As the small-leaved linden and the English elm have best withstood the smoky atmosphere, drought, severe

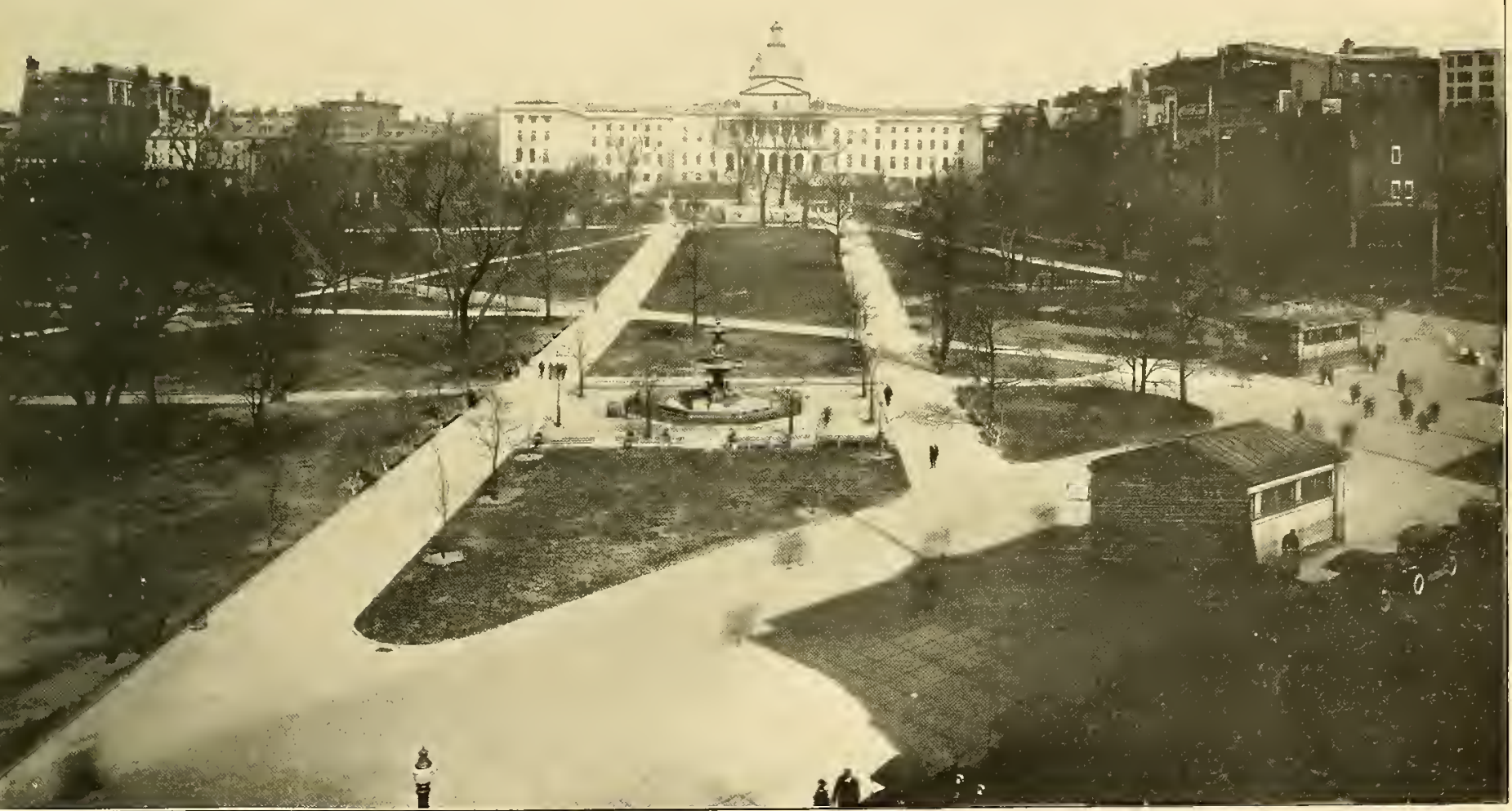

BOSTON COMMON. GENERAL VIEW OF LIBERTY MALL TAKEN FROM TREMONT STREET LOOKING TOWARD THE STATE HOUSE.

winters, and attacks of insects, these trees have been used in all the new plantations. All trees are frequently inspected for insect pests, and spraying is carried on systematically. Tree pruning and repair work is carried out when required. Trees which become too old and decrepit to respond to special care are allowed, out of consideration of public sentiment, to stand, until they die branch by branch or until ice storms or wind complete their destruction. Young trees are then replanted to replace them.

Plans have been made during the past two years showing the location, name, size, and condition of every tree on the Common. Soil improvement facts are also recorded. The position of desirable tree locations and needed soil improvement areas are also recorded and used systematically at each planting season. Substantial tree guards are used with all newly planted trees to protect the bark from injury, and to prevent boys from elimbing and breaking the branches. 
The expense of making, maintaining and storing the plank walks which were formerly used extensively in the autumn, winter and spring on the gravel and maeadam wallis of the Common to avoid the nuisance of mud, led to a long seareh for permanent materials for walk construction. Brick laid dry and in mortar, block pavements, shect asphalt, special types of gravel and erushed stone paths, smooth concrete slabs with ruled joints, rough conerete with hidden joints, monolithie eonerete with curbs east with the slab, flagstone, loose pebbles, and many other types were tried. It is frankly admitted that the old fashioned gravel, brick or flagstone walks are the most pleasing to the cye, but with prevailing methods of snow removal by power serapers, and under the stresses of the weight of trueks, granolithie slabs have proved to be the most practical materials for the wide

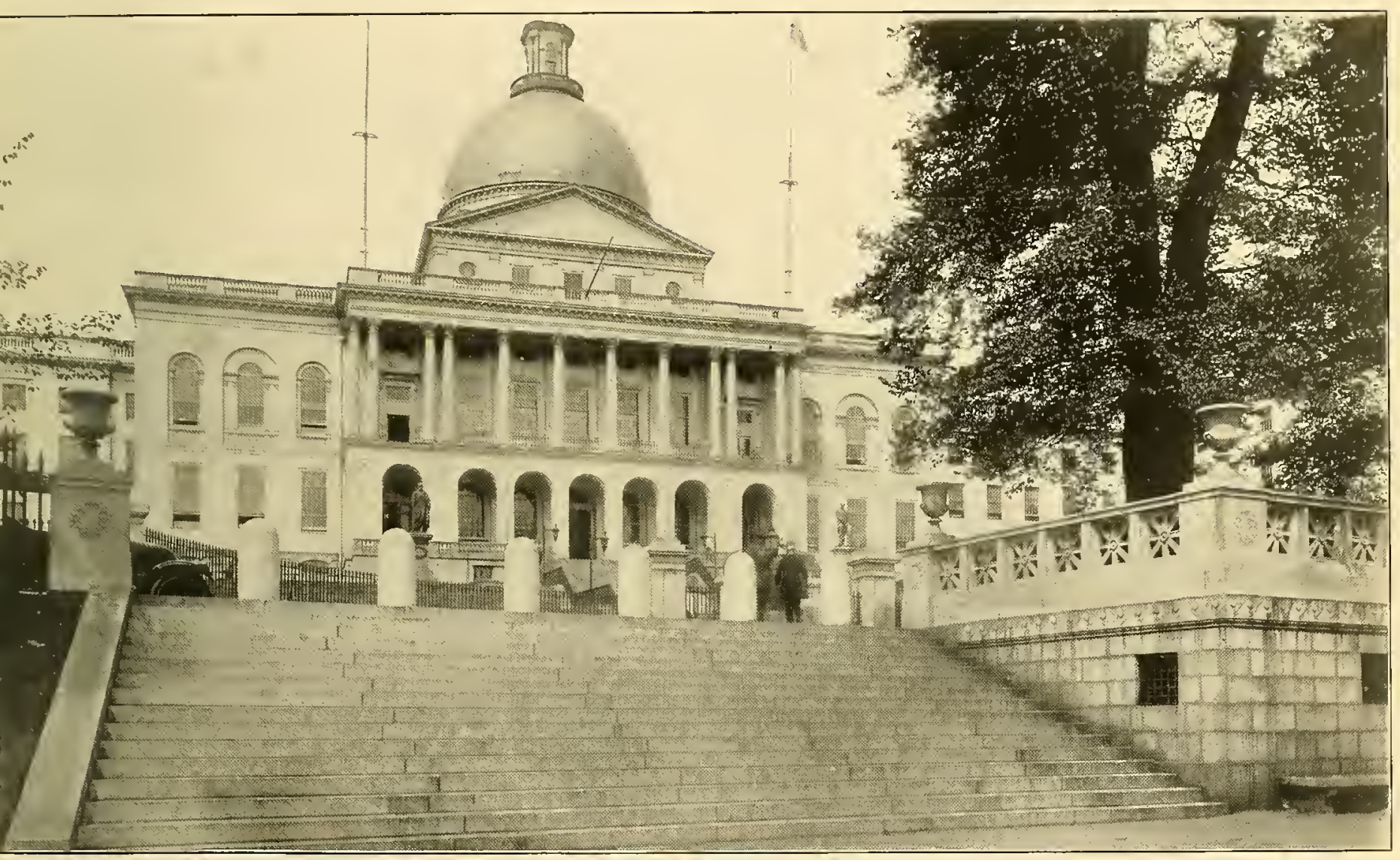

GENERAL VIEW OF ONE OF THE FLIGHTS OF STEPS AT THE HEAD OF THE LIBERTY MALL.

malls over the subway roofs, and for the intensively used narrower paths. The Charles Street and Beacon Street Malls present so extensive a surface and have thus far carried so few foot passers, that these footways have been allowed to remain with gravel surfaces. Experiments are being made to find a method of staining the concrete slabs to reduce their glare and whiteness without impairing their strength.

In adopting permanent materials for the walks, the cost of construction became so serious a factor that certain walks which were used chiefly for local cross-cutting were given up, and other walks which had become worn to unnecessarily great width by eareless upkeep were made narrower. The reduction in the total area of walks also reduced the cost of cleaning and repairs, and at the same time added agreeably to the extent of the grass areas open to public use in hot weather and gave larger space for the growth of the roots of the trees. In certain instances these changes were regretted as they changed the 
loeal appearanee of the districts affeetcd, and reduced the number of convenient shortc1ts, but as a whole the public has approved thc ehanges. The arrangement of the paths forming the Liberty Mall (dedicatcd October 27, 1917), and the relocation of the Brewer Fountain, was also brought about during the pcriod of changes noted above. All this work was donc after full discussions of the problems in the press, at public hearings, and in eonfcrence with soeicties cspecially intercsted in the preservation of the Common. As a wholc the appcarance of this public open space has been improved greatly, though the quaintness of the old dirt paths has been lost. The use of the Common has greatly inereased in the meantime both as a sitting and walking plaee, and as a mere cross-cut zone. Less difficulty is expcricnced in keeping "jay walkers" from walking on the grass alongside the paths, as the paths are now smoother and dryer to walk upon than the grass.

Among other changes whieh have taken plaee of late is the rearrangement of seats and paths at the Parkman band stand, the construetion of a public sanitary on Flagstaff Hill, the creation of a new path forming an extension on the Common of the Boylston Street Mall of the Public Garden, the widening of Boylston and Tremont Streets to a curb width of forty-thrce feet, the widening of Park Street, the flooring of the Frog Pond with a conerete bottom to render this pond a cleaner plaee for wading, the erection of a new fenee and entrance gateways at the eorner of Charles and Boylston Streets, the widenings of the traveled way of Charles Strect, the erection of new gate posts of old pattern at the Charles Street and Park Square entrances, and the erection of many permanent seats.

These changes on the Common have been made in accordanee with the general plan which is shown on Plate IV. With a few minor ehanges the struetural work is now practically complete, but the eare of the trees and the general upkeep of the grounds is a difficult problem always present. It is the purpose of the Park Department to maintain the trees, grass and paths of the Common in a high degree of excellence, and to keep its original character intact. In this important work the bequest of Francis Parkman has been a most practical aid.

In commemoration of the reunion in Boston last summer of the Veterans of the Grand Army of the Republic, trees were planted in the Common on Monument Hill. These trees were placed where they would secure the best sunlight and in specially prepared soil. Markers of marble, properly inscribed and placed near each tree, indicate their relation to one another in symbolizing the States of the Union. 


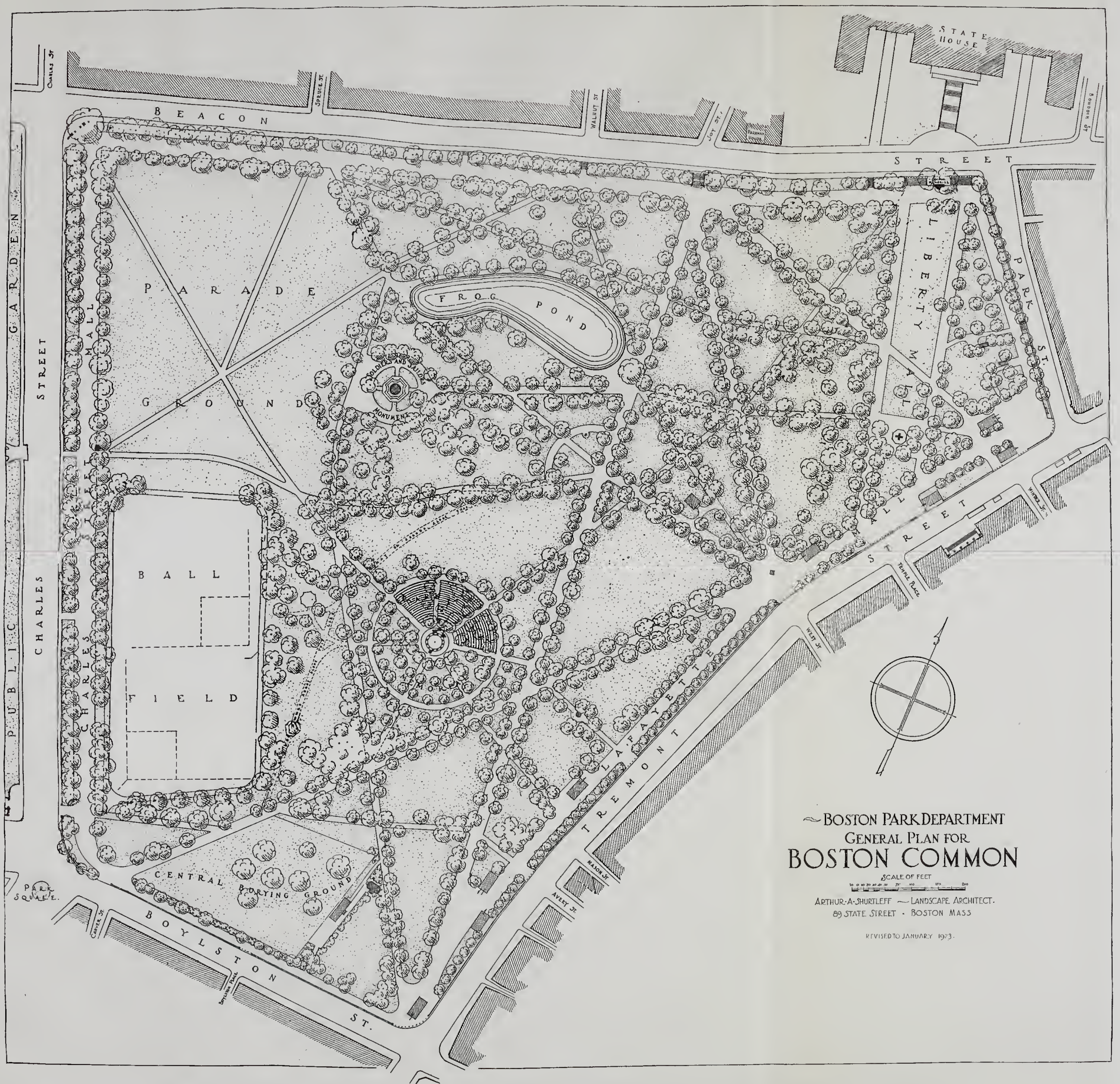

PLATE IV.-GENERAL PLAN SHOWING DEVELOPMENT OF BOSTON COMMON. SEE DESCRIPTION ON PAGE 5 



\section{THE FENS PLAYGROLND.}

The extraordinary growth of schools, colleges and other educational institutions near the Fens, between Brookline Avenuc and the Art Museum, has brought thousands of pupils into a region which is well equipped with park areas, but which has lacked playground space especially for school games of baseball and football. When the first schools were built, the pupils used vacant lots on the upland for their sports. Subsequently when the low wet land of the Fens was reclaimed from salt marsh, this flat ground, although intended for park lawns and for tree and shrubbery areas, was eagerly sought by the schools for ball fields. These demands upon the park became more frequent and more urgent as the number of schools increased. As time passed, it became apparent both that some permanent provision should be made for these playground activities, and that these play spaces shotild not be allowed to preëmpt so great a portion of the park as to change its landscape character. In the neighborhood between Simmons College and Jersey Street the demand for ball fields had already required a resurfacing of the ground, and it became evident that this play area was destined, unless organized, to destroy the shrubbery and grass areas further east toward the Art Museum. The Park Department therefore decided to develop the western portion of this area to accommodate two regulation baseball diamonds, and to define this tract definitely for such use by fences, marginal plantations, and border walks. Beyond these limits, the park landscapes were to be restored and developed in accordance with a carefully studied general plan.

The first steps toward a realization of this improvement are now under way. Ground within the space reserved for playground purposes has been graded. The surrounding plantations of trees and shrubbery, which will give shade and hide the necessary back nets and other structures of the field, will be installed. To avoid the unsightly appearance of temporary wooden grandstands and to meet the pressing demand for spectators' benches, the Department is constructing permanent concrete bleachers of good design. The height of this structure is limited, however, to five rows of seats in order to prevent it from interfering with views across the Fens from roadway to roadway. A field house of low height is to be built against the bleachers where it will be as inconspicuous as possible. Within the building public toilets will be built, and a limited number of lockers and shower baths will be installed. All these constructions and the back nets are to be hidden as fully as possible by vines, high-growing kinds of shrubbery, and by lowbranching trees.

The public footways of the park are to be carried around the marginal screening plantations of the playground. Therefore, to pleasure seekers wishing to enjoy the landscapes of the park, the playground activities will not distract attention from the river, and from the reasonably ample borders of sedgy ground, grass land, and the slopes rising to the roadway. Refercnce to the plan on page $\mathbf{2} 2$ and the bird's-eye view on page I I will indicate the gcneral character of the work under way and contemplated. See also pages I 3 and I4 for a description and plans of the proposed development of the region adjacent to this playground, opposite the MIuseum of Fine Arts. 


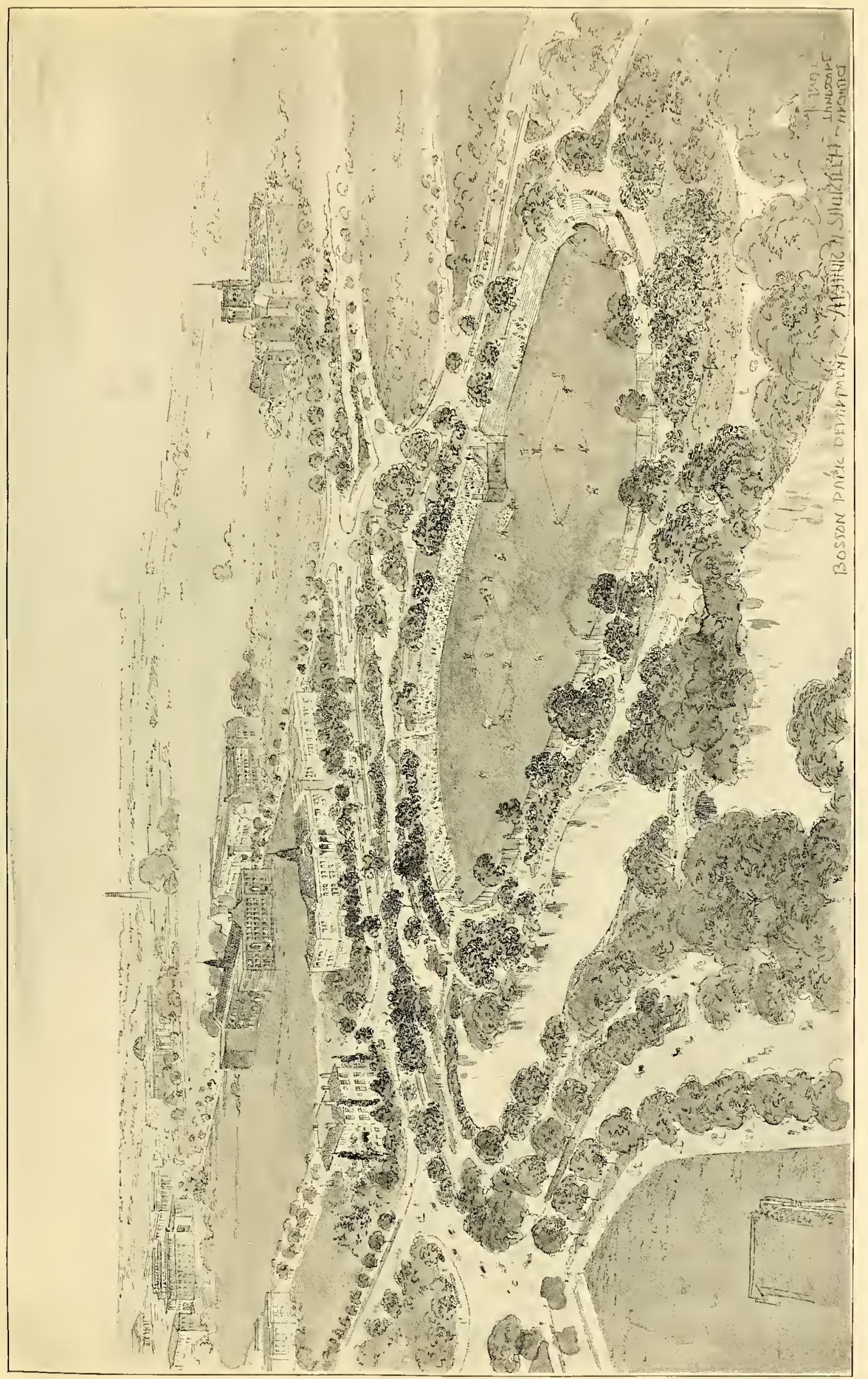




\section{PROPOSED FENS IMPROVENENT OPPOSITE THE ART MUSEUM.}

Referenee has been made on page Io both to the need of providing playground space in the western section of the Fens, and to the desirability of developing adjaeent portions in a park-like manner in keeping with the landseape idcals of the Park System. A start is to be made toward the general landscape improvement of the Fens, by the development of the traet opposite the Art Museum. Reeognition of this building is possible in the design of the park by arrangements of water, meadow land, and woodlands to form

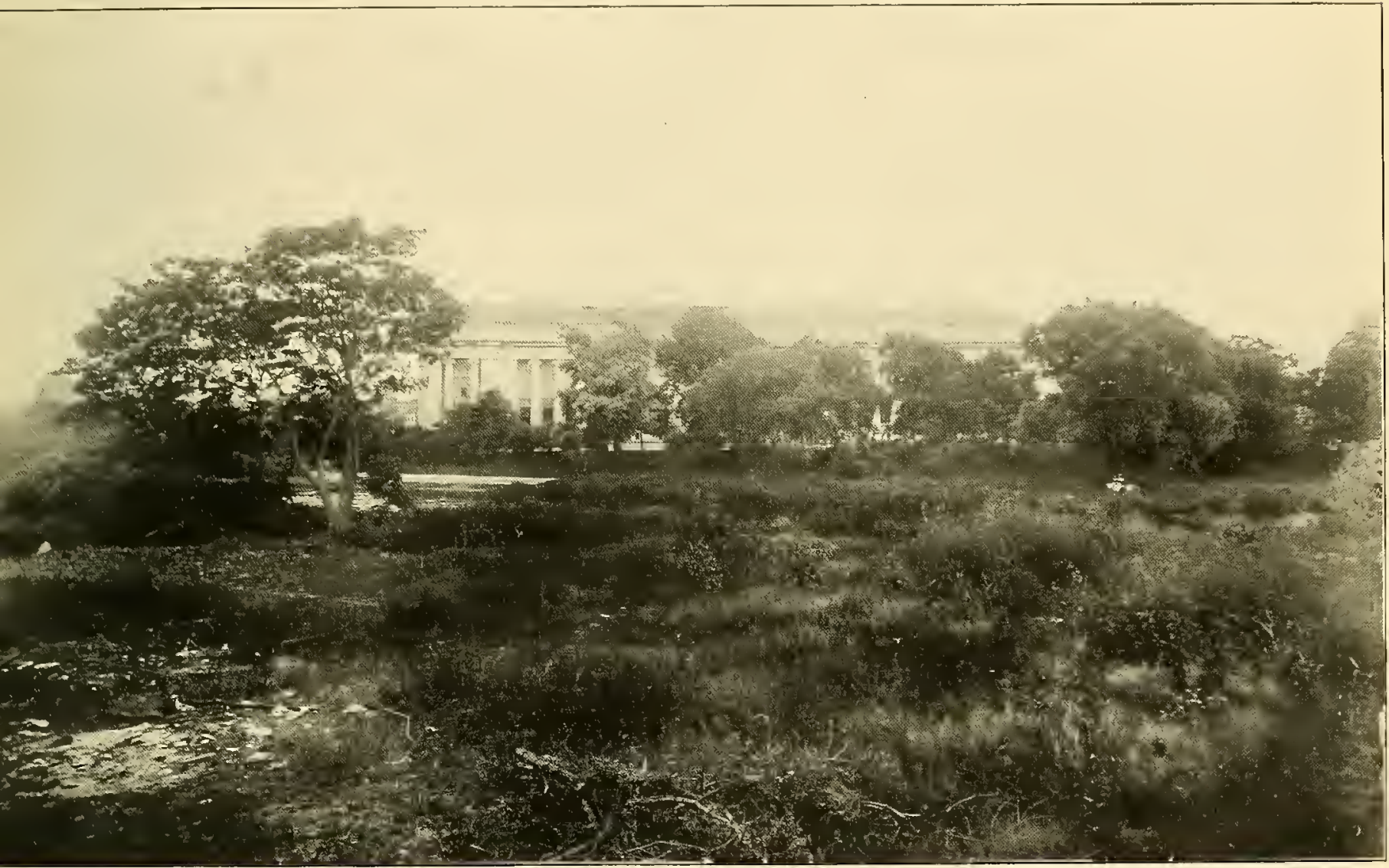

BACK BAY FENS. VIEW SHOWING PRESENT RELATION OF GROUND, WATERWAY AND TREES TO THE ART MUSEUM. vistas for the enjoyment of visitors who approach the Museum, and also for the pleasure of those who enter the park from the direetion of the galleries. Evidently this loeal adaptation of the landseapes of the park to the Museum should not be earried so far as to ereate formal eompositions appropriate to this edifiee but at varianee with the eontinuity of the naturalistie landseapes whieh give unity to the Park System. It is also evident that speeial loeal compositions of this kind, even though naturalistie in eharaeter, eannot be repeated often in the Fens without danger of a loss of unity in the design of the park. With these reservations in mind, the Park Department proposes to create opposite the Museum a landseape eomposition in harmony with the park and arranged to display the northern portico of the building pleasantly and frankly from the roadways, paths and lagoons. This landseape treatment is to be studied earefully for composition as seen from the building, and from the roadways, paths and stairways which give aeeess to the park opposite the building. 
A description of the plan and bird's-cye view of this improvement (see page I 2 and Plate VII) briefly is as follows: The curving park roadway and bridle path which pass the front of the Museum are to be straightened to form lines parallel with the building. Using a portion of the space thus gained, the stream opposite the center of the building is to be widened to form a reflecting pool or lagoon of sufficient size to accommodate boats. The trees which now obscure the Museum from this aspect (see photograph, page 13) are to be rearranged to frame the portico of the building as shown. To accommodate pedestrians wishing to cross the path toward Jersey Street, two paths are to be provided, one from the Huntington entrance and the other from the Ruggles Street entrance. Two bridges, symmetrically placed, are to be built to carry these footways across the stream at each cnd of the lagoon. A broad flight of steps also connects this path system with the lagoon

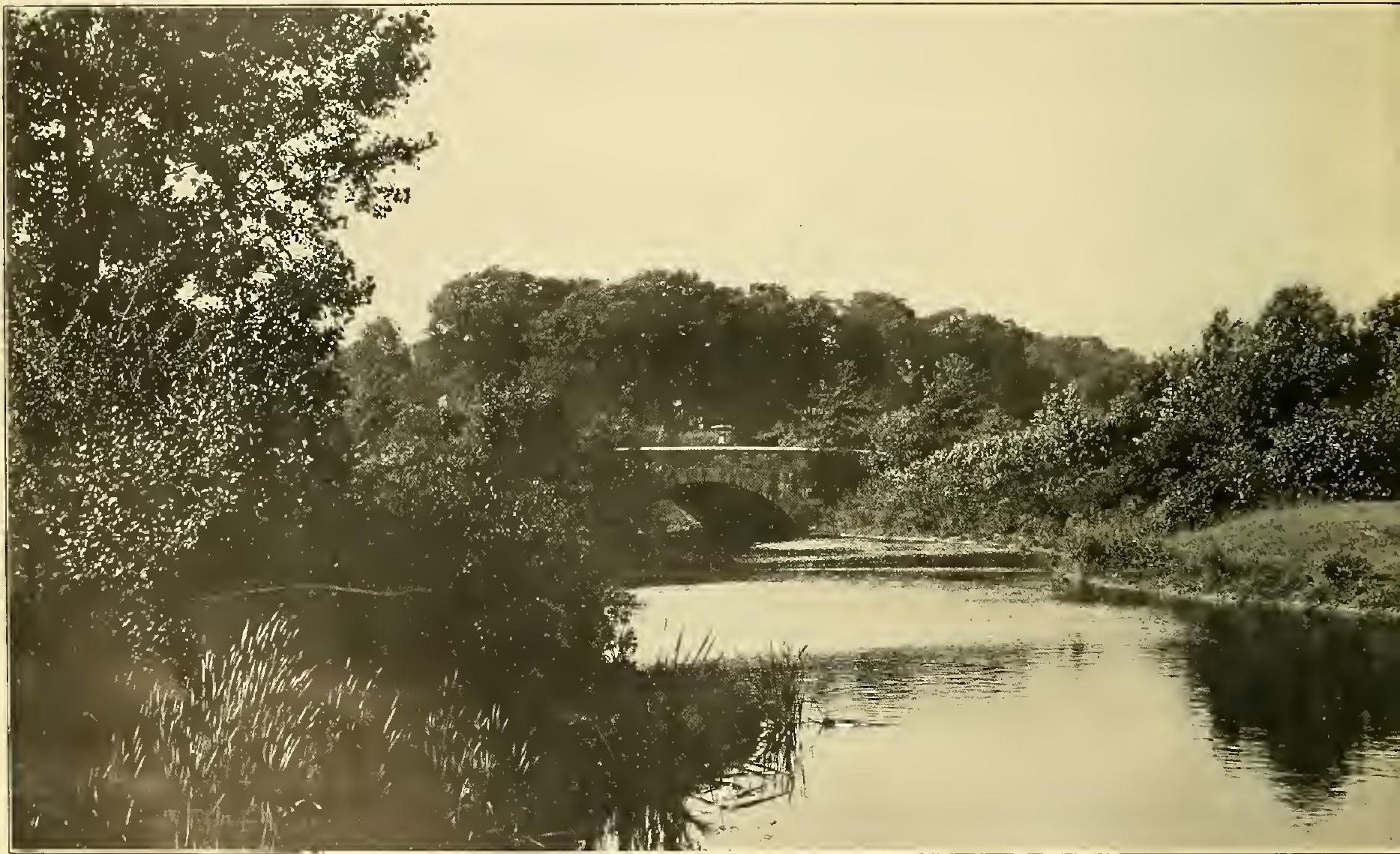

STREAM AND BRIDGE IN MUDDY BROOK PARKWAY.

and the footways at the Museum entrance. Opposite the stairway a landing platform for boats and a low terrace with a balustrade is to be installed. Beyond the lagoon to the north, a large space of open meadow is to be maintained. This open space is to be flanked by scattered trees and groves, but sufficient openings are to be arranged to give good vistas across the intervening meadows and the water to the portico of the building. Studies of the angles of sight have been made in deciding the location and extent of the pool to insure good reflections of the great colonnade. The east-west path system follows the margins of the composition without detour, and connects the bridges. Plantations of shrubbery and trees are to be set out to give shade for the paths, to form screens, and in general to support the margins of the open spaces. This work has been planned to harmonize with the plan of general development of the Fens as a whole. 


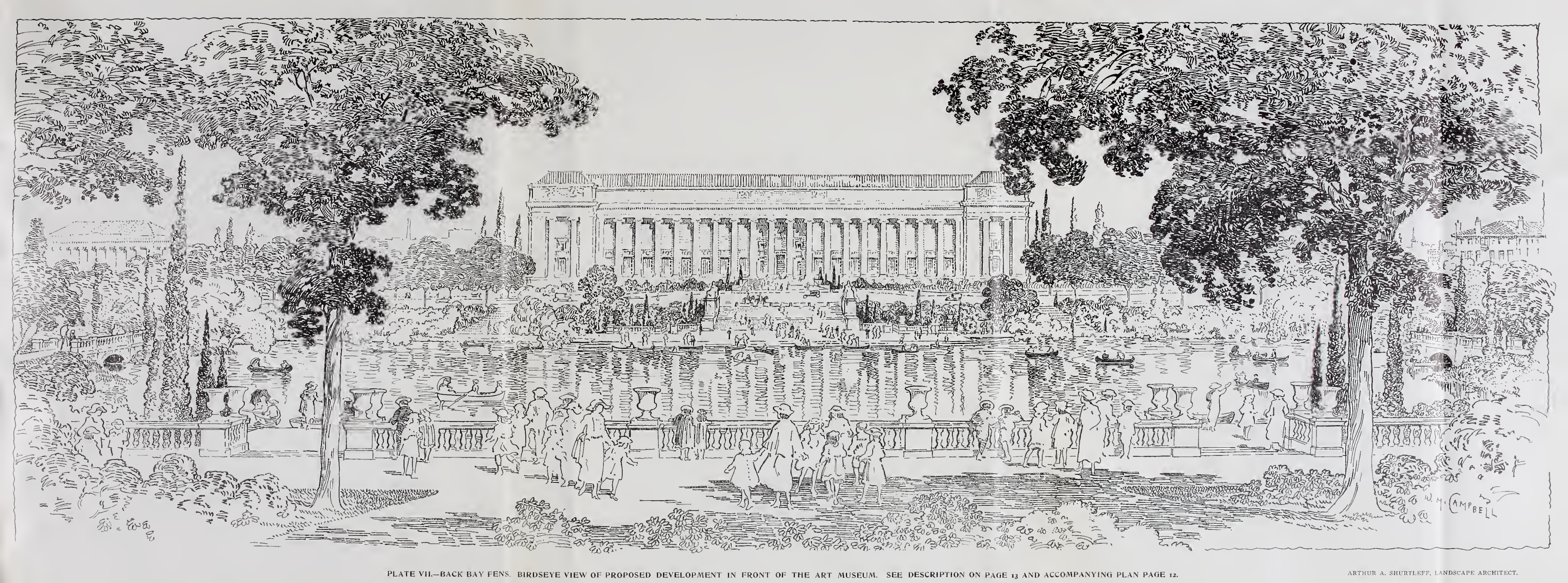


1 (3)

(1) (1)

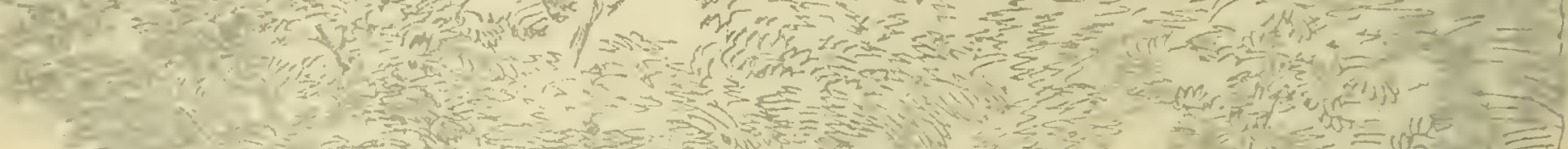
PE

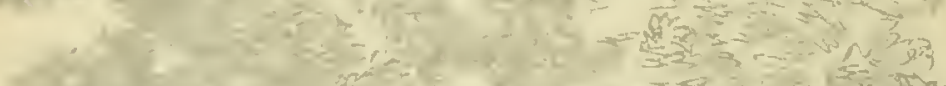
(2010

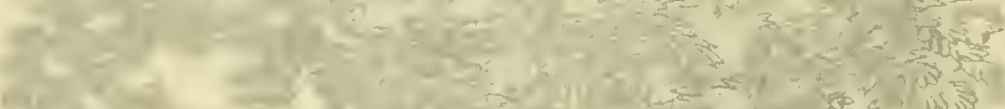

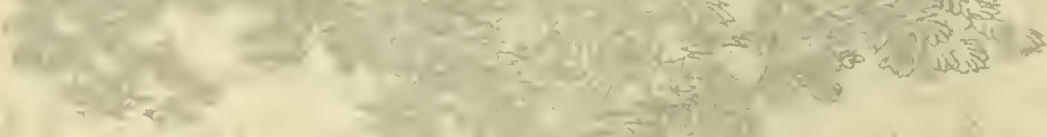

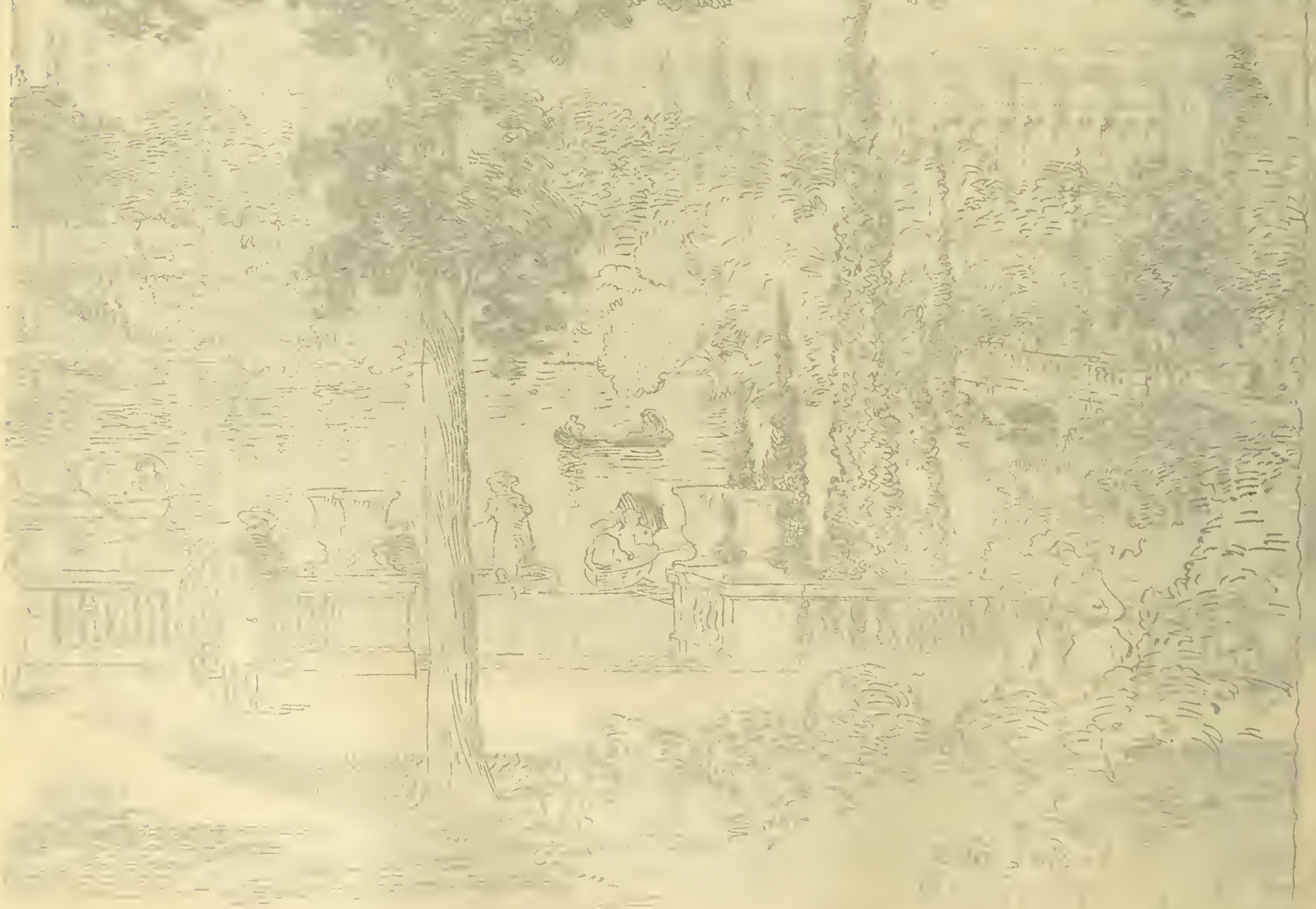




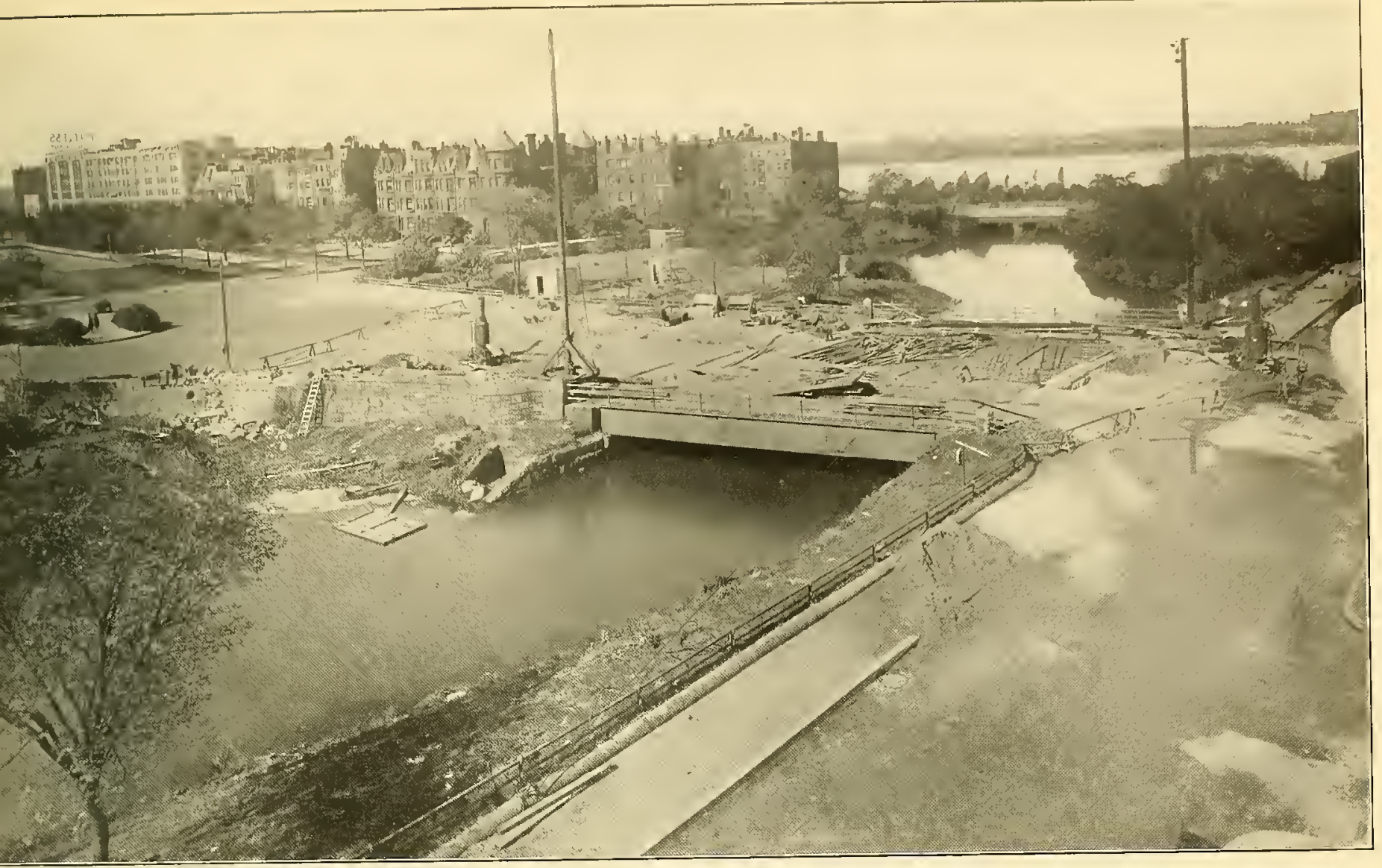

ERPL VIEW OF COMMONIVEALTH AVENUE AT CHARLESGATE SHOWING CONDITION OF ROADWAYS AND WATERWAYS DURING CONSTRUCTION, PREVIOUS TO IMPROVEMENTS.

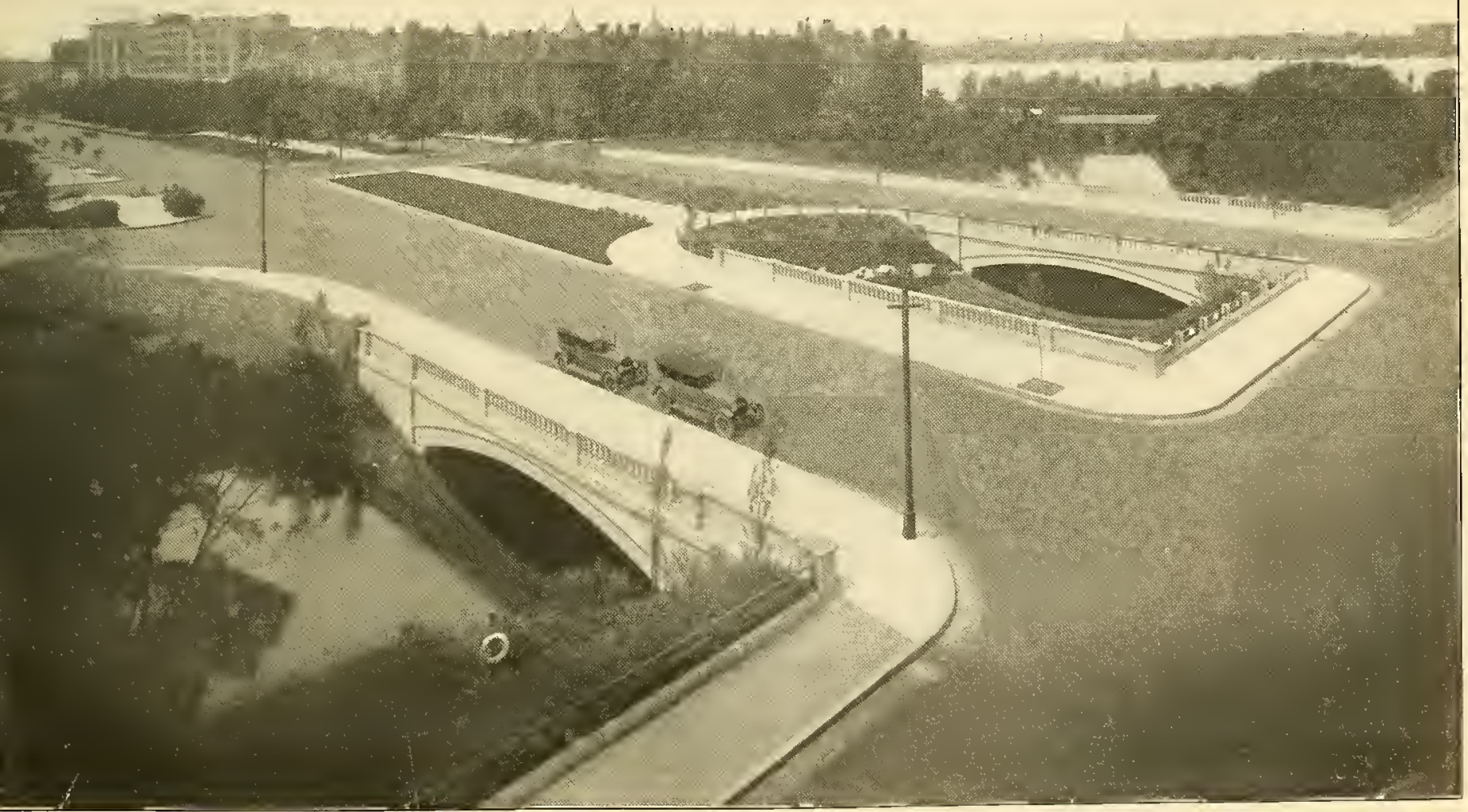

GENERAL VIEW OF COMMONWEALTH AVENUE AT CHARLESGATE WEST, SHOWING NEW BRIDGES AND ROADWAYS. 


\section{THE ZOO.}

Great importance should be laid upon the point that this spccial tract devoted to a collection of animals and to the Rose Garden and its adjacent Herbaceous Garden, to the Mall and its terminal colonnade at the Peabody Circle, should not bc made a part of the landscape of the great naturalistic "Country Park" which is the controlling composition of Franklin Park. The most precious landscapes of the Park System and of the countryside about Boston are in Franklin Park. There is little chance that these landscapes will be excelled. The Zoo is a unit which must be kept within the topographical and landscape bounds which now define it. If it were allowed to encroach upon the "Country Park" or if amusements which are appropriate to the Zoo were allowed to find a place in the heart of Franklin Park, very serious harm would result. The heavy and high screening plantations which border Glen Lane were deliberately designed to protect the landscape of the "Country Park" from the irrelevant and, therefore, disturbing attractions which were permitted to find a place on the ground now devoted to the Zoo. Similarly, the heavy woods north of the Playstead were maintained at their full height and density to screen from the landscape of the park a collection of native animals which it was thought might find a place upon the ridge among the trees. Fortunately the bounds which frame and screen the Zoo are ample for the accommodation of a thoroughly satisfactory and reasonably extensive collection of animals. There is nothing in the size or contour of the ground or in the location of this tract which can handicap it in becoming one of the most important Zoological Parks of the country, or to justify trespass upon the great "Country Park."

The Zoo is confined to the limits of ground described above, and it uses the border screens of trees which are essential to the "Country Park" as a useful background and shelter plantation. Buildings of low height and quiet color are used in order to present a group of structures as inconspicuous as possible when seen from without. Interior plantations of trees are an important element of the plan of development. They are arranged to reinforce the present boundary screens, to provide shade between and within the enclosures, and to give a sense of space and separation. (See Plate VIII.) Trees are to be planted in naturalistic groups except along the Mall, which is an adaptation at less width of the original formal "Greeting," intended to be used as a great entrance esplanade for the accommodation of horse-drawn carriages, riders and pedestrians. The exhibits of animals, birds and flowers are arranged in symmetrical groups where they are associated with the Mall, but elscwhere they are placed in conformity with the rolling and ledgy contour of the ridges and hills. Buildings of picturesque type are used wherever a departure from regular forms has been possible. Temporary buildings for housing deer, elk and bison are built without attempt at picturesque effect, and the simplest materials and methods of construction are used. In erecting permanent structures, the Board has aimed to provide buildings which are best adapted to the health of the animals, and which will give the greatest satisfaction to visitors to the park. It can be said without hesitation that each permanent building thus far erected is the best of its lind in this country and provides shelter for exhibits which are not excelled elsewhere. 


\section{BOSTON PARK DEPARTMENT \\ FRANKLIN PARK}

GENERAL PLAN FOR ZOOLOGICAL GARDEN.

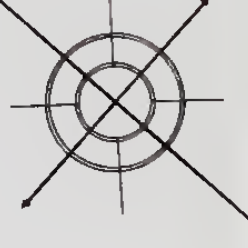

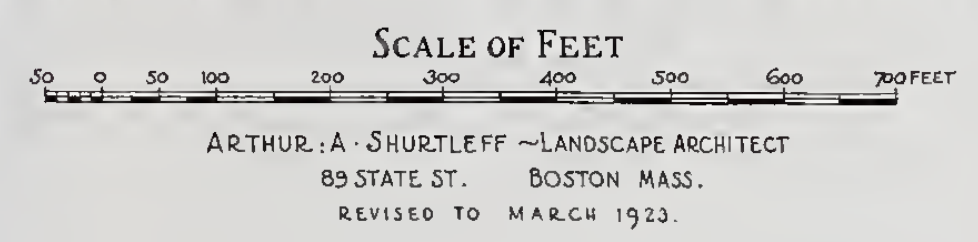

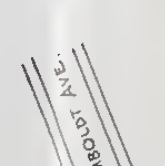
(2)

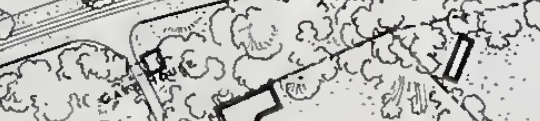

D.

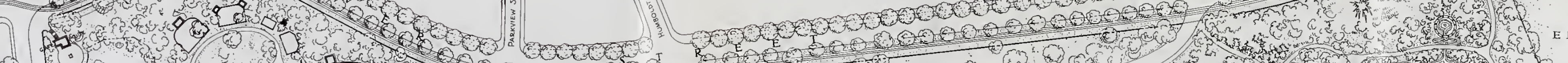

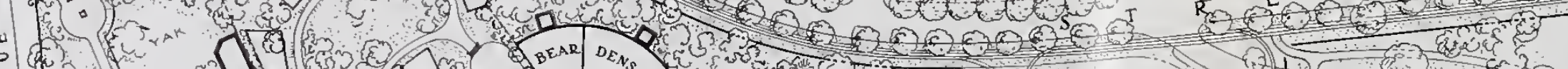

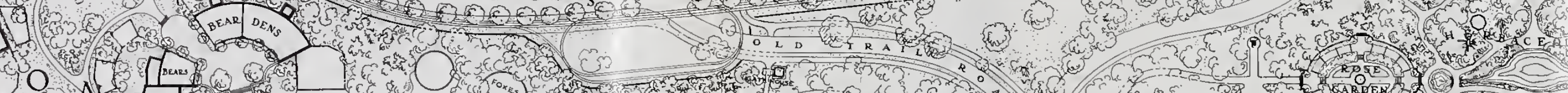

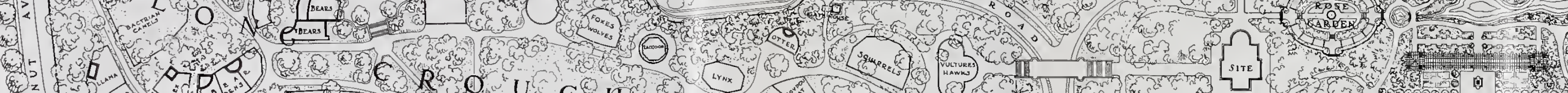

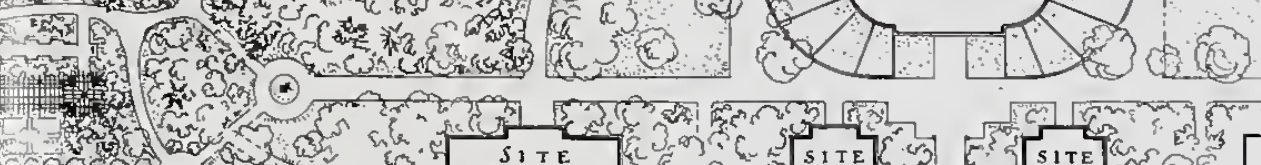

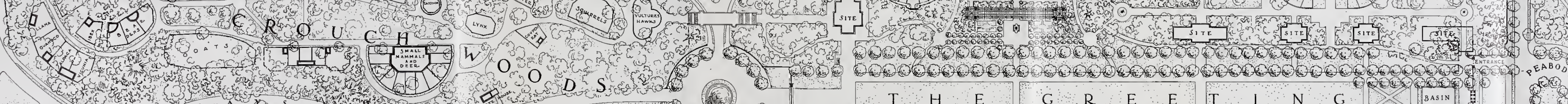

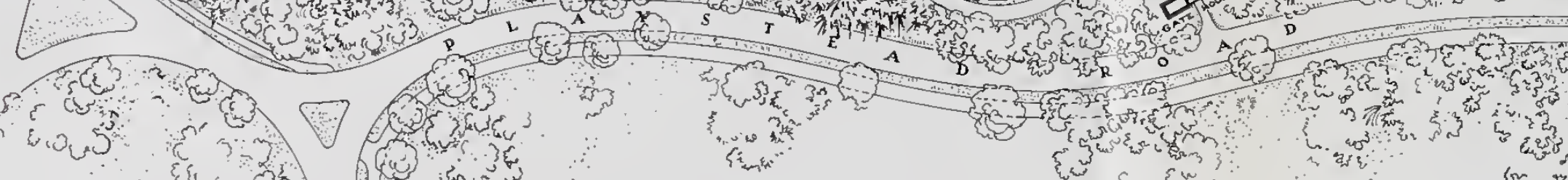

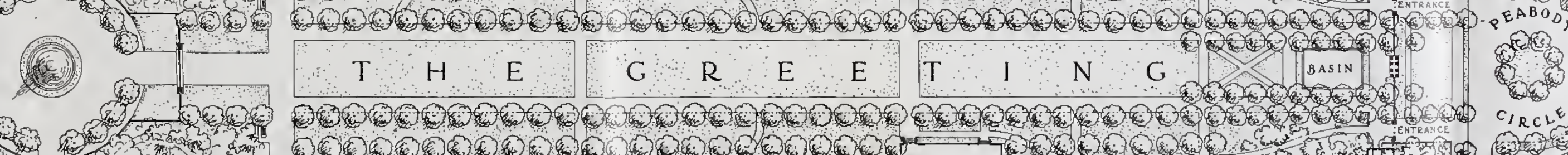
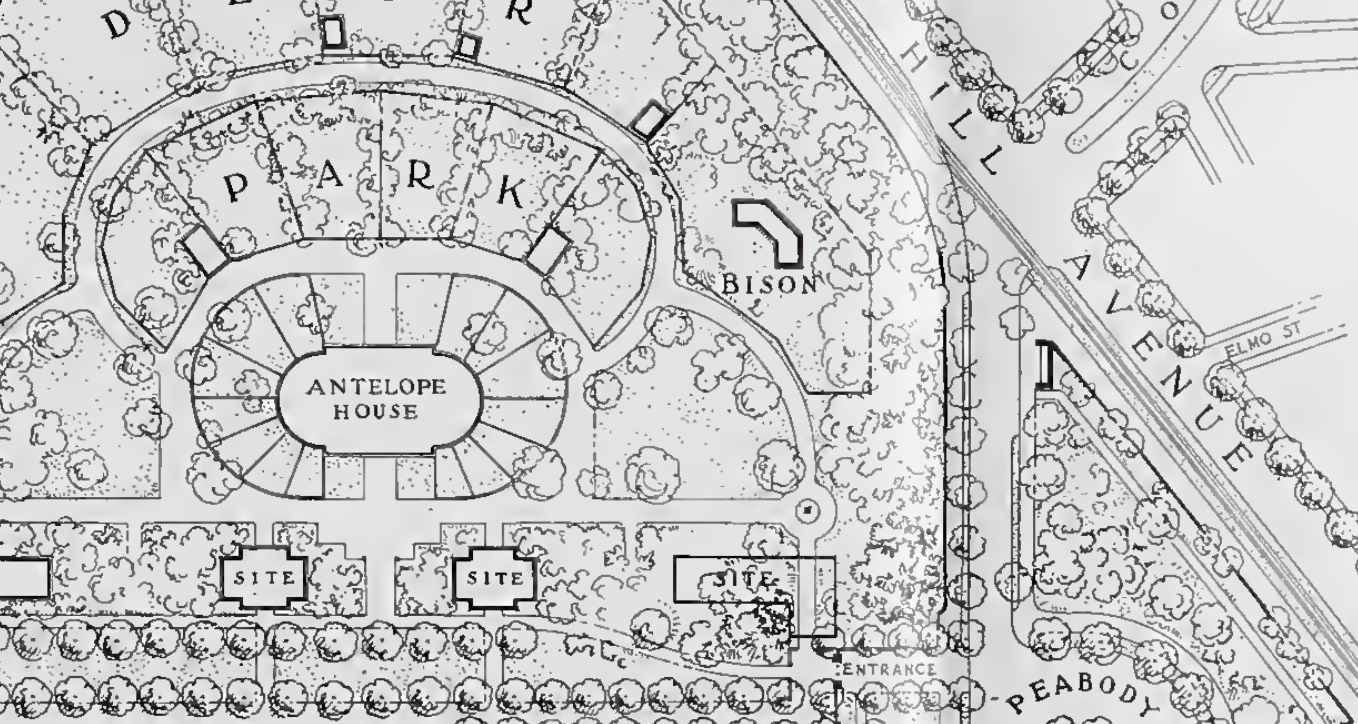
s.t. हn

THE P L A Y S T E A D H 


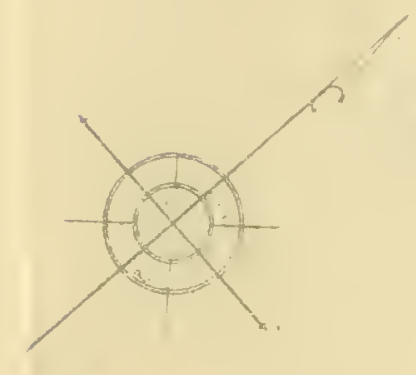

1

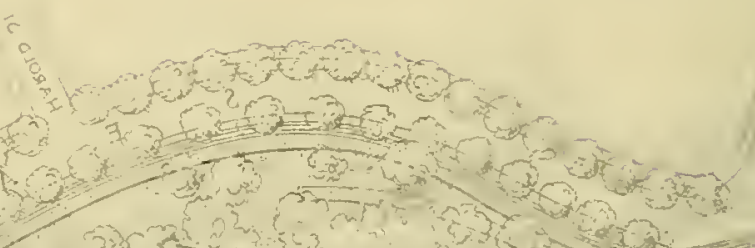

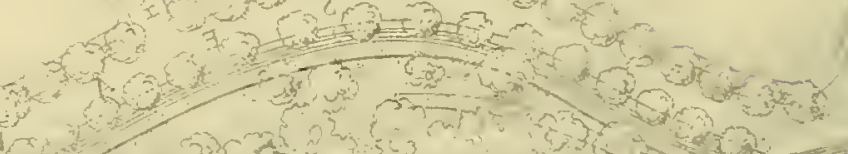
m.

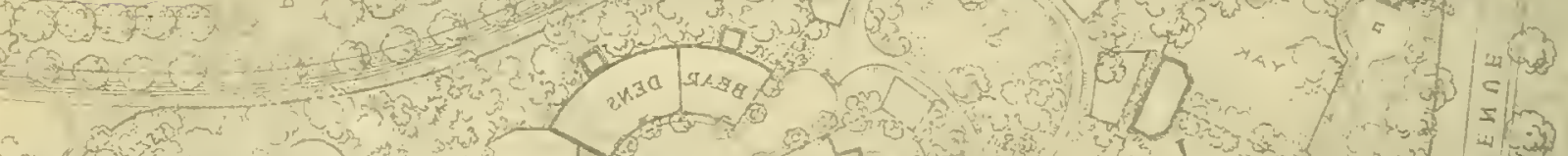
m.

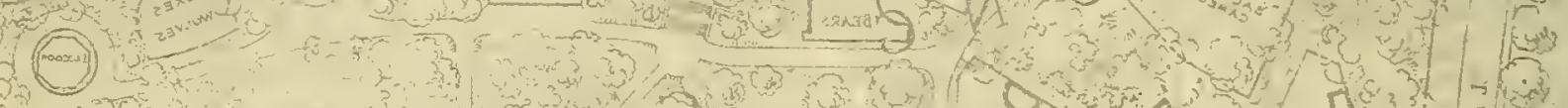

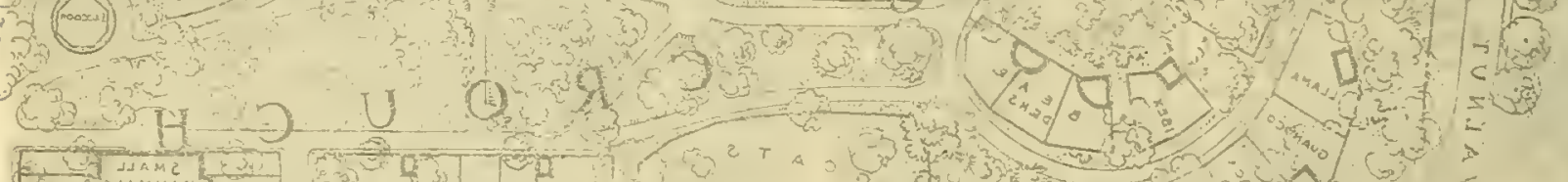
F, LIt

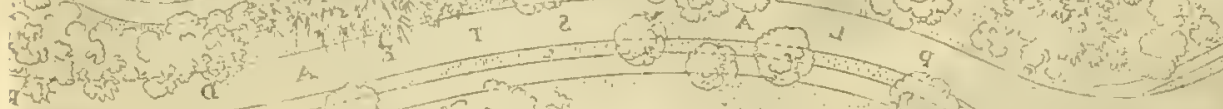
तent की

A $\exists T 2$ T A I G $\exists H T$ 3दिध

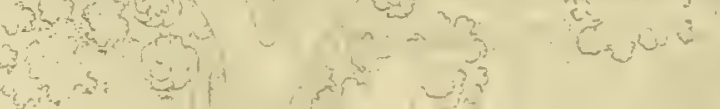

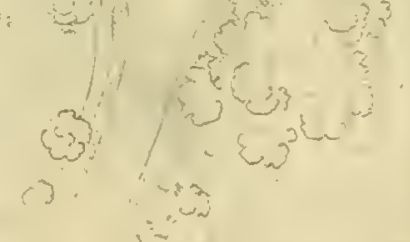


A large element in the suecessful development of the \%oo has resulted from the constant adherenee to the general plan of layout which was adopted when the first exhibit (the bear dens) was installed. Improvement of the details of the plan has followerl special study devoted to each new aequisition, but the gencral plan has not been the sulject of change. Consequently, the Zoo has taken form rapidly. Public attendance has increased far beyond expectations. The recent development of the elk and decr ranges, the cxtension of the much needed Mall plantations, and the construction of the Rose Garden (see Plate IX) have awakened new public interest and cnthusiasm for the Zoo. It is hoped that the grading of the Mall can be completed before another season. This improvement will greatly assist in handling the crowds of sightscers, and it will form an important scenic addition to the work already completed.

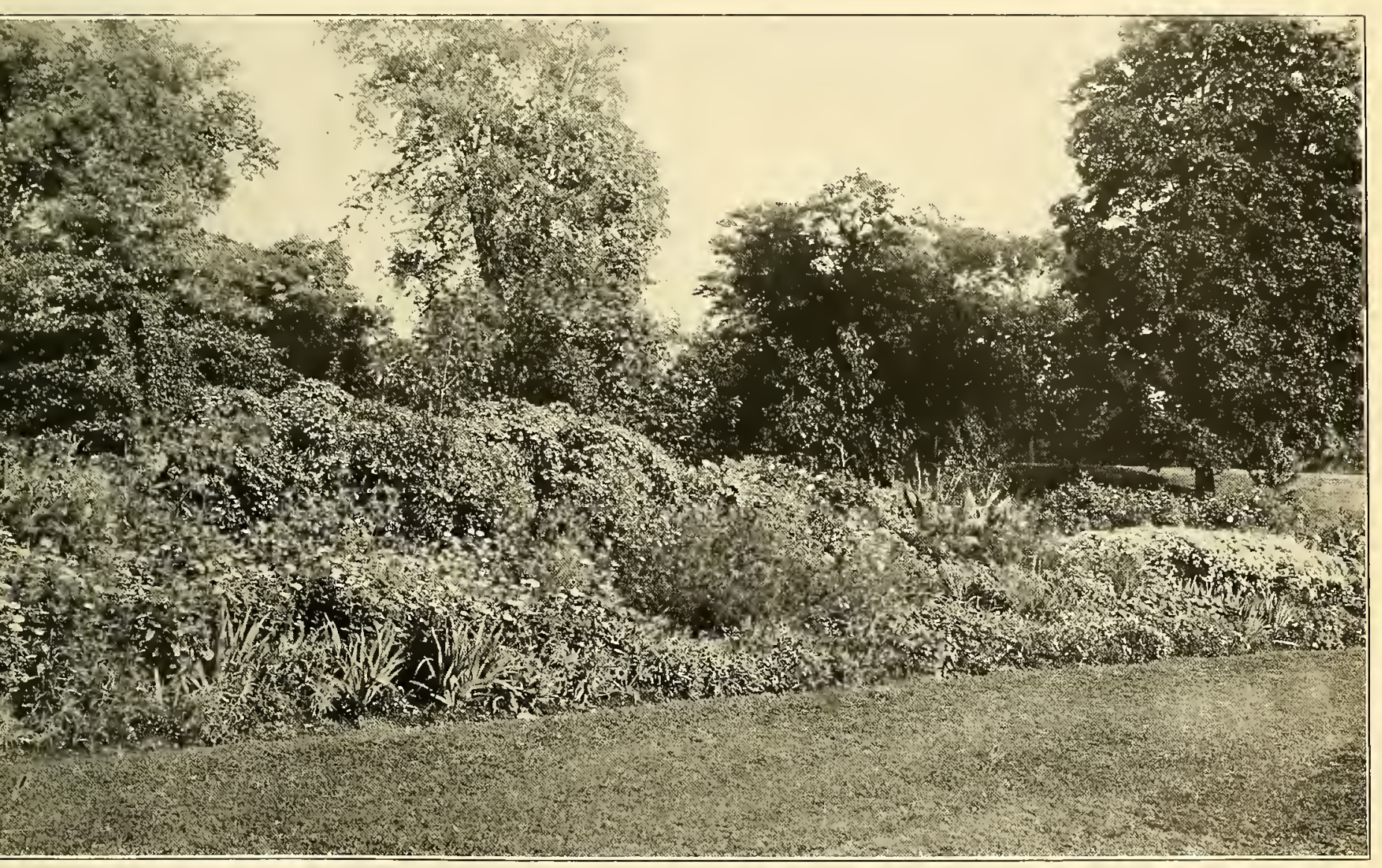

FRANKLIN PARK ZOO. A PORTION OF ONE OF THE FLOWER BORDERS OF THE HERBACEOUS GARDENS. 


\section{THE ROSE GARDEN.}

Over two years ago his Honor Mayor Curley brought to the attention of the Board the growing popularity of rose garden displays in City parks. Near at home, in Springfield and in Hartford, displays of this kind attract great crowds to the parks on Sundays and holidays, and bring flower lovers to these centers from all parts of New England. The time seemed ripe for the creation of a garden of this kind in Boston. After thorough study a satisfactory site was found near the Herbaceous Garden in the Zoo at Franklin Park. General public approval of this project followed, and much interest was shown by the local flower and garden clubs, horticultural socicties, and by organizations and cities in the West. Working plans were consequently prepared and the garden has now become an accomplished fact. (See general view on Plate IX.) To save a season's time, the first installation of roses was made in the spring of 1923, as soon as the ground was graded, but before the walks, trellises, fountains and the walls of the garden were built. These structures were partly completed during the following summer, and thousands of visitors evinced their interest by visiting the work to see the roses during the period of construction. The rose arches, the gates, and other details of the garden were finished during the following winter, and the garden was opened in completed form last May. Over seven thousand roses will find a place in the garden. The best roses which can be grown successfully out of doors in this climate will be used. Pillar roses, climbers, standards, dwarf and other types will be grown. Upwards of eighty-four varieties have already been set out.

In form the garden is oval. The central panel is sunken and is approached by four flights of steps. In the center is a circular water basin and fountain. Trellises resting on a curtain wall of concrete, and interrupted by massive concrete piers, form the enclosure of the garden. Upon these trellises and walls, climbing roses are grown. At the four cardinal points of the oval, attractive concrcte niches and arches are built to give points of ascent, and to provide gateways. Permanent construction is used throughout the garden and it cannot fall into ruin through need of repairs in the wooden panels of trellis. Around the garden flowering shrubbery and trees have already been planted.

The general location of the garden is at the westerly end of the lagoon proposed for the future extension of the Herbaceous Garden. (See the general bird's-eye view, Plate X.) Shelter from the wind and a southerly exposure to the sun have been found here on ground which lent itself to the form and the extent of the garden and to the need of well drained soil. A natural background of large trces was also present. The main path system of the Zoo leads to the site, and near it are placed the most important exhibits of the Zoo, including the Bears' Dens, the Bird House and Flying Cage, the Elephant House, the Lion House, and the collections of deer and elk.

It is estimated that the number of visitors to the garden during the season of construction was in the neighborhood of fifty thousand. 



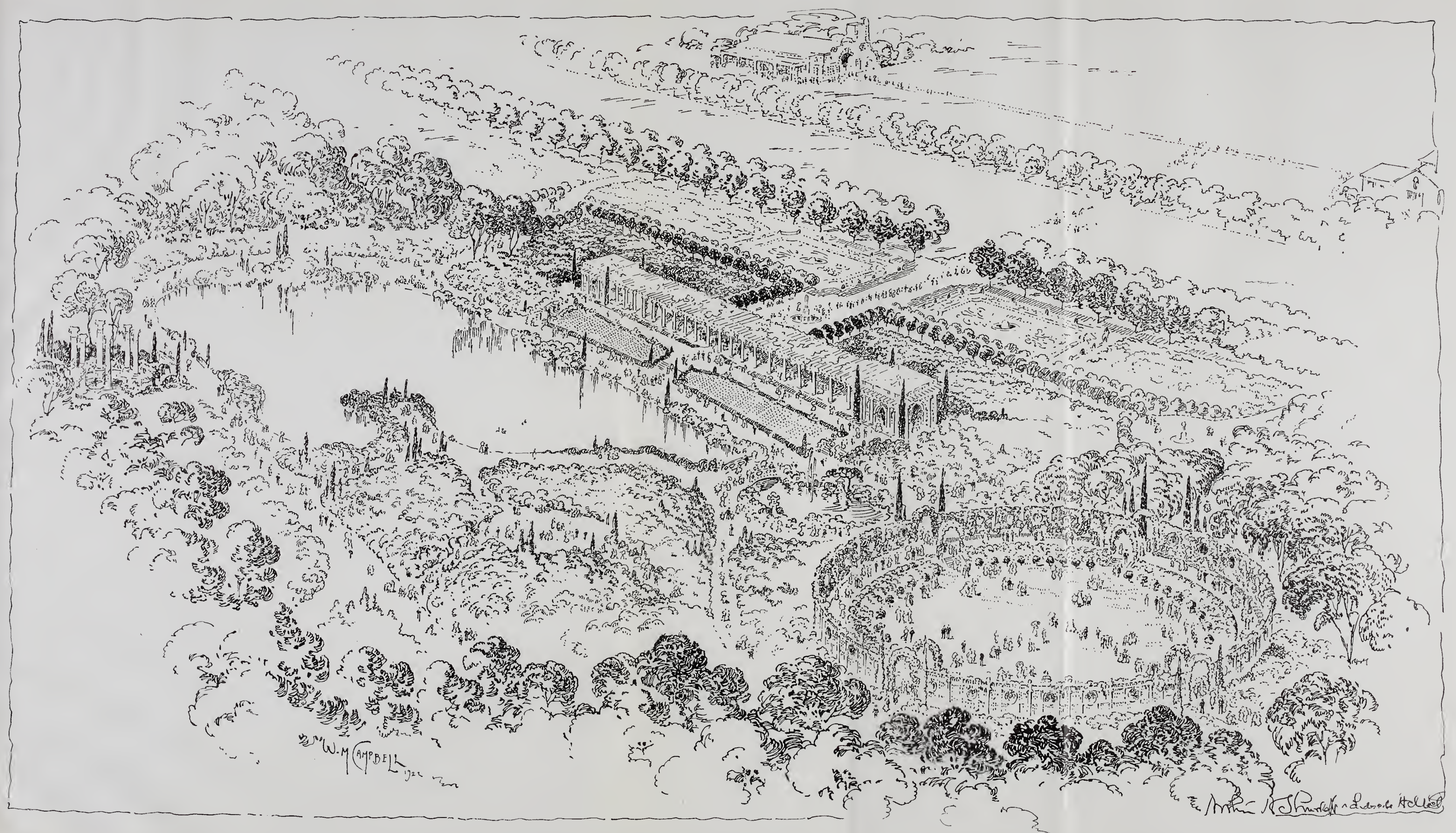




\section{CHRISTOPHER GIBSON AND JOHN A. DOHERTY PLAYGROUNDS.}

The effective arca of this playground has been vastly increased by the addition to it of that portion of Gcneva Avenue which lies between the two triangular parts of the field. Although this strip of street did not exceed 5o fect in width, its acquisition has unitcd the detached parcels, onc of medium size and the other of small size. The single tract thus formcd is of distinctly ample size for gencral playground purposes. This change has also greatly rcduccd the dangers which formerly involved the approaches to both sections of the playground, and it has simplified the problem of providing locker building facilities and supcrintendence. Under the new arrangement of streets, one field house can be made to serve both areas, and at most seasons, a single caretaker can oversee play on both play areas. Persons approaching or leaving the park by trolley cars are accommodated by a convenient landing platform which has been installed as a part of the rearrangement of tracks involved by the street changes. Briefly the playground is now one of the most satisfactory local areas for intensive recreation in the City.

The ball field has been regraded to give a nearly level surface to accommodate a full sized diamond with space for a small diamond of 60 feet. High fences surround the diamonds to keep the balls and the play within bounds and to localize the foot entrances. The latter are placed nearly opposite the adjacent street intersections in a convenient relation to the bleachers and to the play spaces, but they are subdivided with substantial posts to prevent the entrance of motor cars. Provision is made, however, to allow trucks to enter in case grading operations or construction work is contemplated.

It was the intention of the Department to place the bleachers at the southern end of the field and arrange in $U$ shape to embrace the infield. In response to the request of residents of the neighborhood, however, the bleachers were built in a single bank of seats along the northeasterly margin of the combined diamond and football field. This grand stand accommodates 2,00o spectators. Toilets and showers for visiting athletic teams have been installed temporarily in the closed space under the bleachers, but these will be replaced later when the new field house is built. The row of trees behind the bleachers has been preserved. The plan on page $2 \mathrm{I}$ shows the general layout, and the position of drinking fountains, the flagstaff, and the other features described.

The lower section of the playground is to be laid out with swing shelters (built), see-saws, and tree plantations to provide shade and to screen the streets. The ground is to be graded to give a satisfactory surface for a play field for the use of girls and small boys. The contour of the surface is to be moulded to permit the flooding and the shallow ponding of water in winter to form a skating place. 


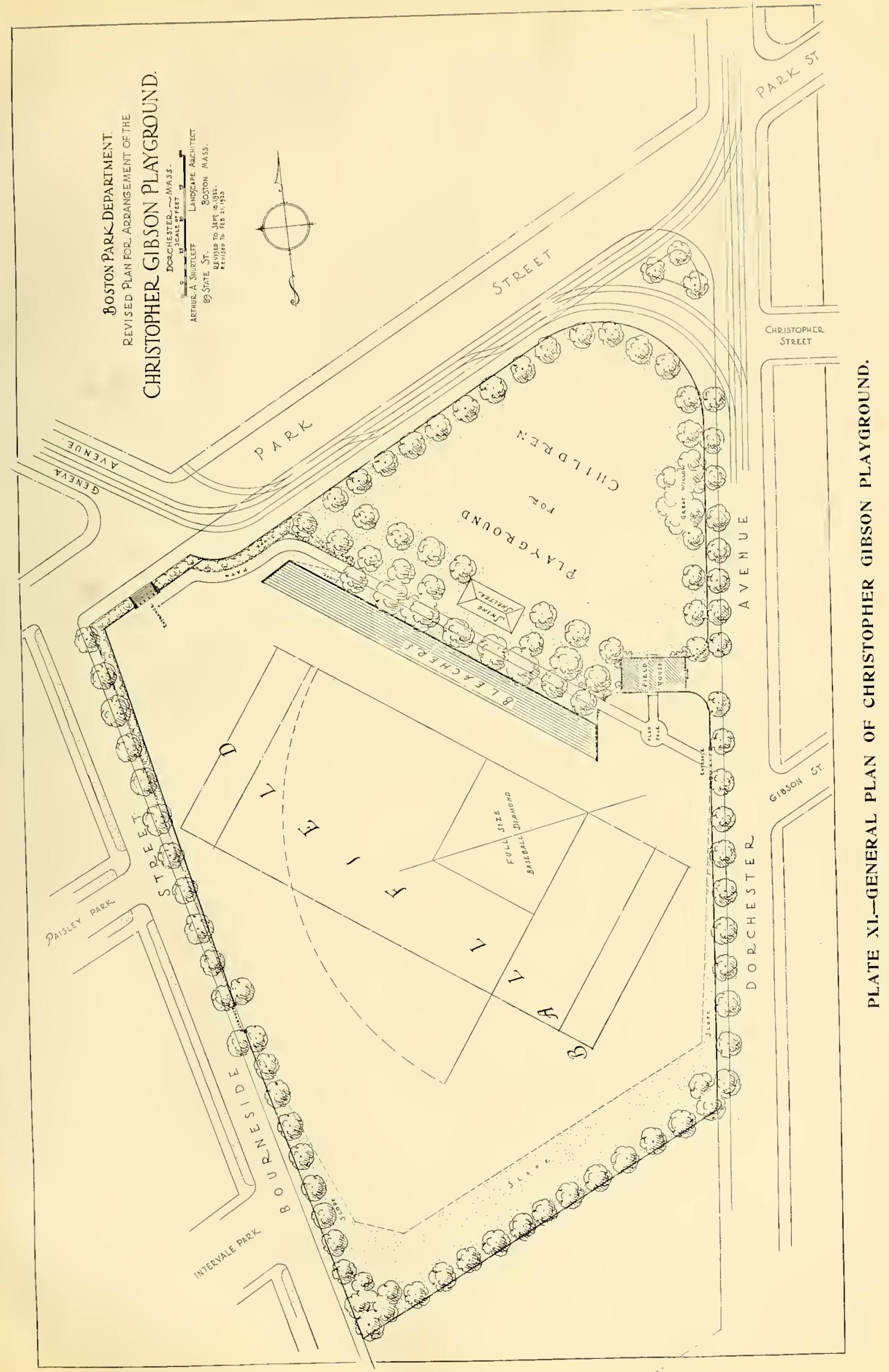




\section{THE CHRISTOPHER J. IEE PLAYGROUND.}

In the casterly section of South Boston, good playground facilities have becn provided by the cnlargement and improvement of the M Strect recreation area. By discontinuing the block of Sccond Street, between M and N Strects, a substantial addition to the play space of the ball fields has been made and has also permitted a relocation of the bleachers upon the steep slope of the higher ground which was previously nearly valueless for park or street purposes. A thoroughfare for foot passers has been arranged across the northerly margin of the bleachers. This footway also furnishes convenient approach to the bleachers from below, and the general path system of Independence Park at the rear furnishes ample approach and good standing room at the rear of the bleachers. The bleachers are constructed of concrete and are provided with continuous wooden seats furnishing accommodations for about 4, IOO spectators. Both baseball fields are served by this extensive bank of seats which stretch along the full length of the football field. By placing the backstops of the ball diamonds at opposite ends of the pair of fields, these superstructures do not interfere with the free use of the combined fields in the football season. In the winter, flooding a large area of the ball fields is made possible by the shallow basin-shaped contour of the ground. Skating can thus be enjoyed when the fields are not used for other purposes.

In the Christopher J. Lee Playground generous space is provided for the use of girls and small boys. This play area is separated by fences, and rows of trees around the margins screen it from the streets and field. Arrangement is made for tennis, basket ball, volley ball, and other sports, but the grounds are subdivided to make baseball on full size diamonds out of the question. In these days when the demand for increased baseball facilities is so insistent, play space for girls and children can hardly be dedicated permanently to their use unless the area is actually unsuited for the play space of the larger boys. Swings and a shelter are provided for the youngest children at the end of the field.

Between the two general subdivisions of the playground, a field house is arranged for the use of both sections. The permanent structure of masonry has ample accommodations for the regular patrons of the play spaces and for visiting teams, and is exceedingly pleasant in general appearance. Lockers, showers, dressing rooms, attendants' office, storerooms, and a heating installation are included in the equipment. The building, which was designed by Messrs. O'Connell \& Shaw, is placed in a location which makes possible an agreeable composition with the great bank of bleachers, the adjacent fields, and the adjacent streets. As a whole the Christopher J. Lee Playground is one of the most conveniently arranged and best equipped open spaces for intensive play in the City. It serves a large section of the City, and is resorted to by thousands of players and spectators. On the event of special ball games, greater crowds assemble here than at any other local public playground in the built-up area of the City. It was named in memory of a World War soldier who lived at 75 Hancock Street, Dorchester, and who died January 3, 1920, as a result of injuries received at the Meuse-Argonne, October 26, I9I8. He was a nember of the IoIst and Iozd Infantry and was promoted to the rank of Major of Infantry on September 24, I9I8. 


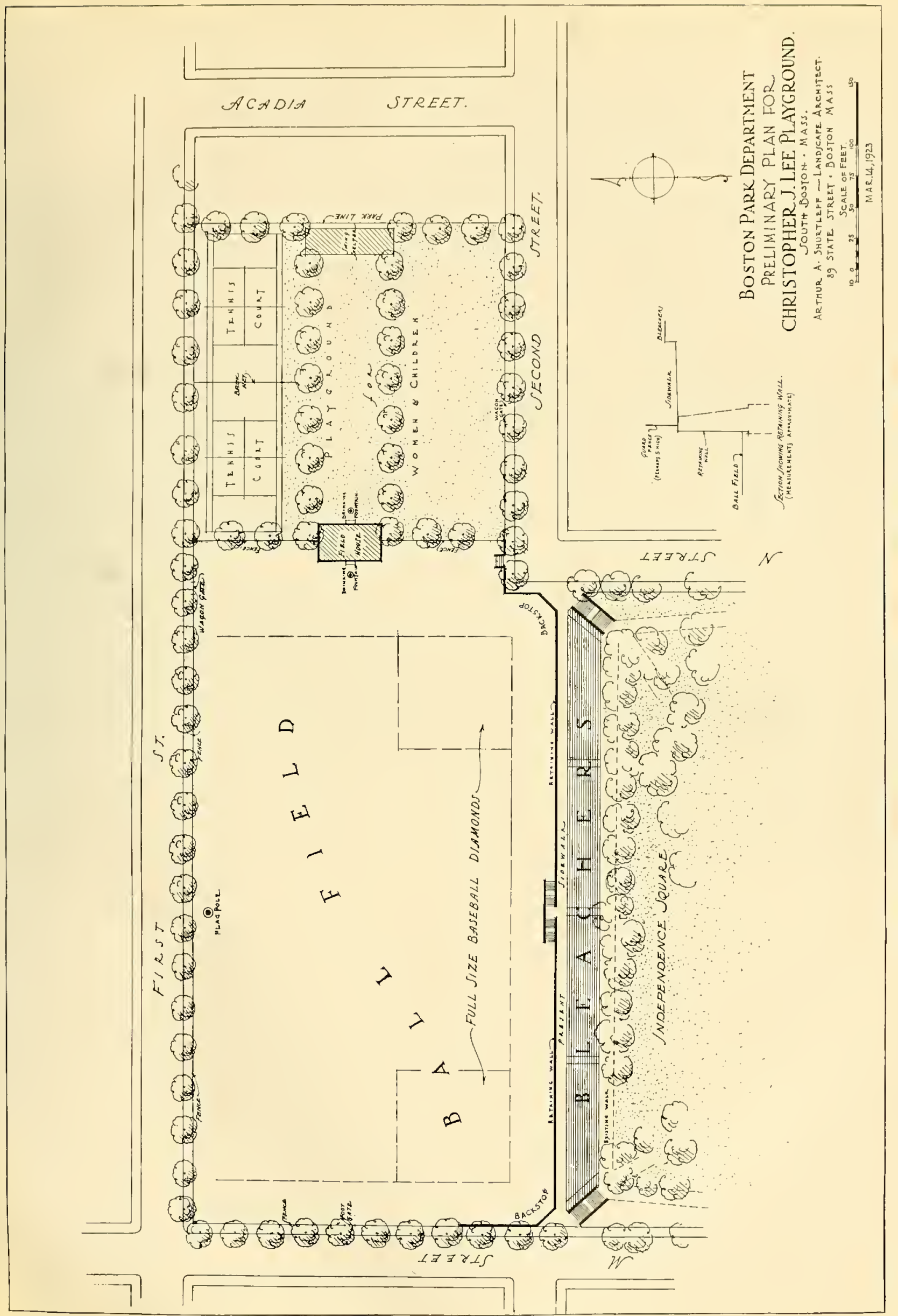

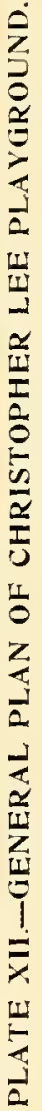




\section{COLUMBUS PARK.}

Columbus Park (see bird's-cye view - Plate XIV and plan - Plate XIII) is approaching completion in accordance with plans adopted by the Board in February, I922, in pursuance of the general program of development which was advocated in the inaugural address of his Honor Mayor Curley. The waterfront boulevard having a length of 3,800 feet is graded, curbed and surfaced. Granolithic sidewalks have been constructed on both sides of this pleasure roadway, and electric lights are installed. Shade trees, bordering these walks, will be planted in the spring. The great circle on the high ground near the railroad bridge has been completed, and motors are using the circle to

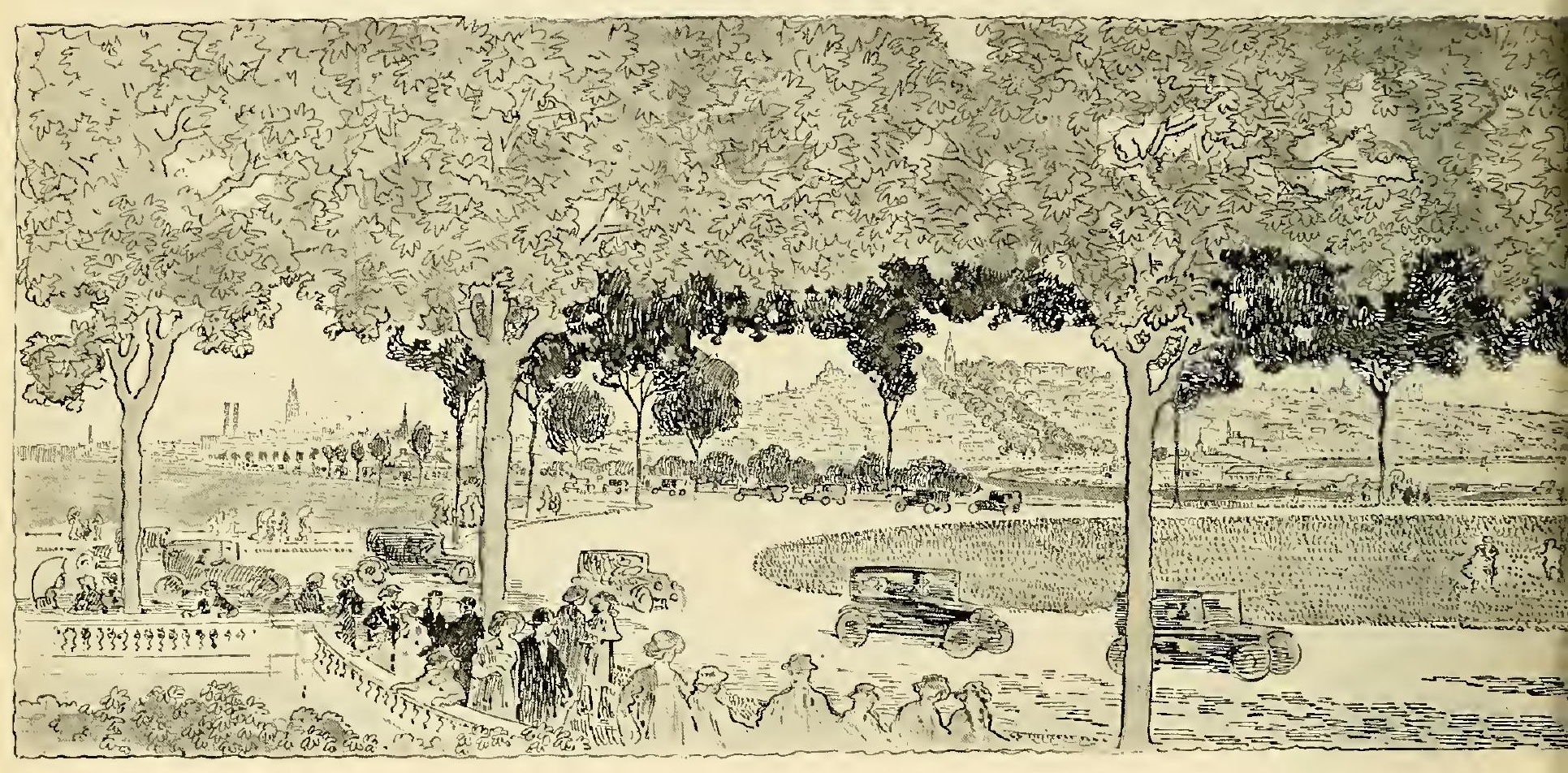

THE CIRCLE AT THE

cnjoy the cxtensive views of the City, the play fields of the park, the bathing beach, Dorchester Bay, and the distant waters of the outer harbor. This circle connects the former roadways of the park and Columbia Road with the new waterfront boulevard. The circle is also arranged to receive and to distribute the traffic of the southern portion of the Old Colony Boulevard when that metropolitan thoroughfare is constructed and connected with the northern section already built. Columbus Park, which is now linked with the City. the Strandway, and Franklin Park, on the north, east, and west, will then be united directly with the southern district and with the main roads leading to Cape Cod. The park will be accessible to a very large population, and its roadways will form important links in the main pleasure thoroughfare of the district.

The new bath house, having a length of 360 feet and with lockers, showers and other accommodations for about 2,000 persons using the beach, is finished and will be ready for use next spring for its second season. The building which is fireproof and thoroughly modern in its equipment is made of brick with granite trim. It stands at the water's edge, at a point about midway of the length of the beach, and is consequently within easy reach 
and reviews. The grading operations, whieh have already been completed in more than half this great area, are arranged to permit the whole or parts of the expanse to be flooded in the winter for skating.

South of the athletie fields, on the rising ground toward the great eirele, space is set apart for grass areas bordered by shrubbery and trees and finished with seats for the aecommodation of those wishing to enjoy a view of the park and of Dorchester Bay. The trees are to be planted in groves to afford shade, but these foliage masses are placed where they will not block the prospects from the eircle or the high ground near it. In faet a portion of the street tree planting of the shore boulevard south of the bath house is to be omitted in order to prevent the obstruction of wide views of the waterfront as seen from the high ground. Approaeh to the groves and grass spaees is to be provided by footways leading from the eirele and eonneeting with the path system of the waterfront. The ground whieh will be devoted to this general treatment is about ten aeres.

Between the upper sections of the Shore Boulevard and the extreme southerly point of the beaeh, a triangular plot of gently sloping grass land is to be laid out. Trees and shrubbery are to be used sparingly, however, in order to avoid the danger of interrupting the water views as seen from the upland and the roadway. Along the southerly margin of the park, however, a heavy planting of trees is to be set out to form an effeetive screen against the industrial district which is springing up on the marsh level. This plantation will form a grove, the eastern end of which will approach the point of land. Upon this promontory an attractive shelter will be eonstructed to afford a pleasant view and resting place for sightseers wishing to enjoy a view of the full sweep of the beaeh from the lower level. This general seetion of the park is subgraded, and the main granolithie walk is built to the point.

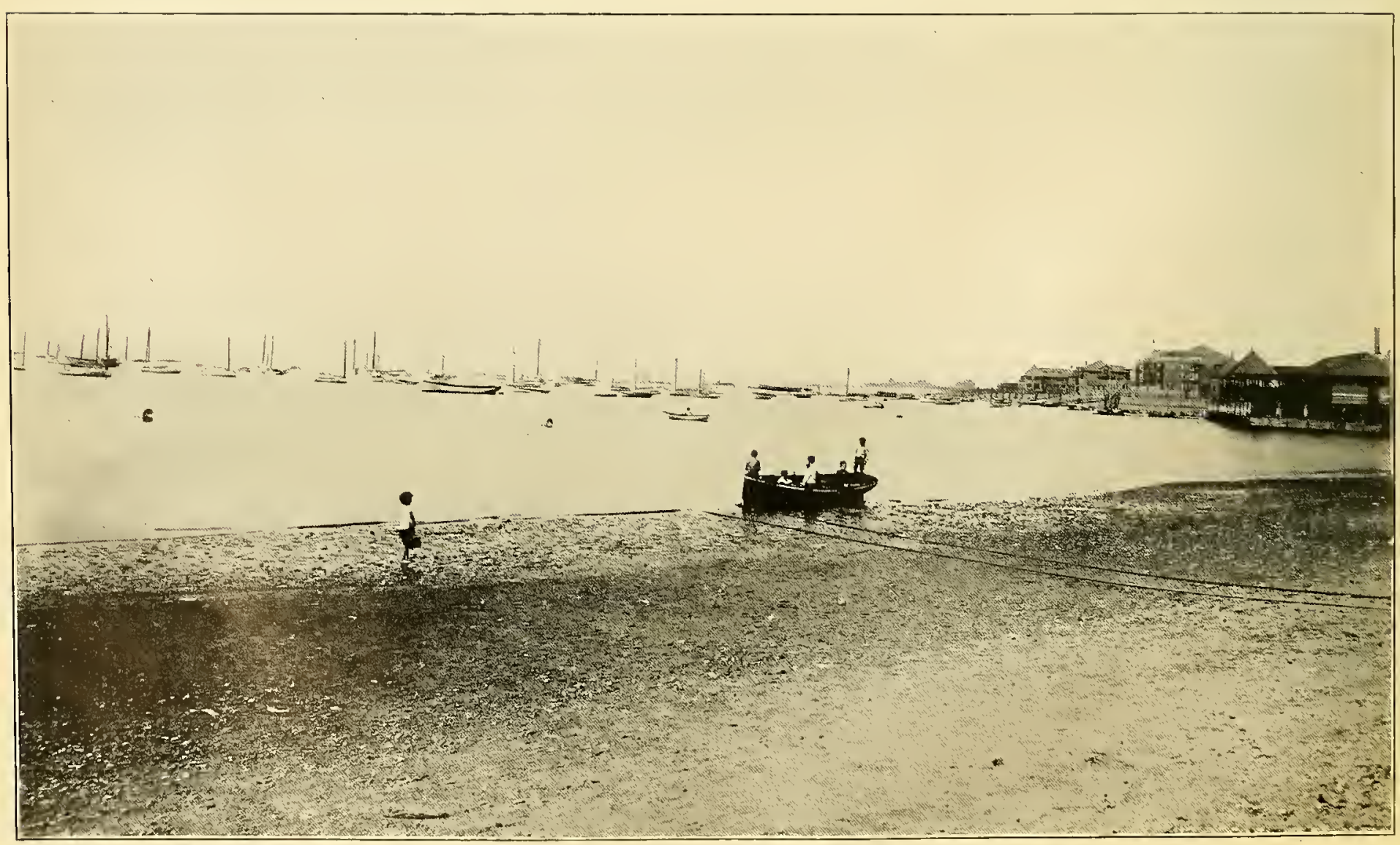




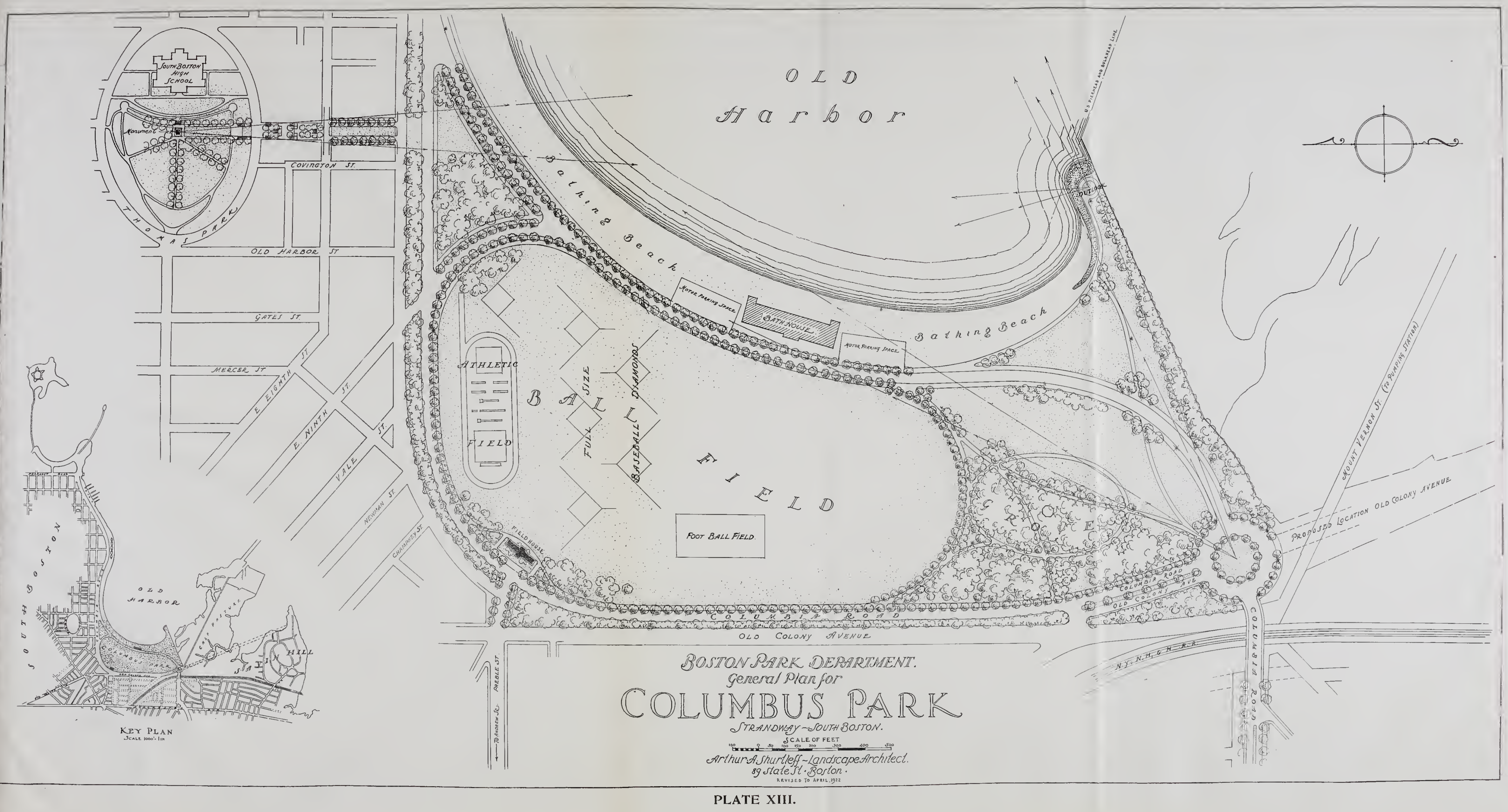




(n)

$-1,3=0$ 10

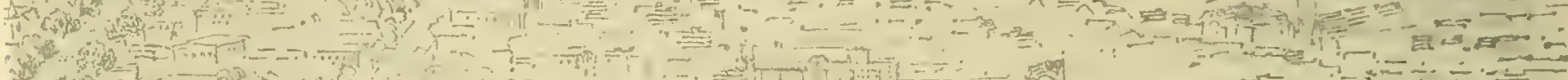
(1) 19

(i)

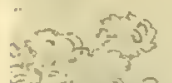

and

ind

$-3=x^{2}$

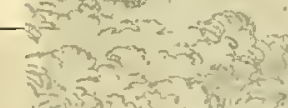

Ant

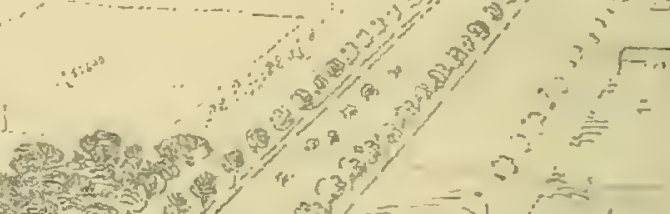




\section{CASTLE ISLAND.}

The growing importance of Castle Island in the development of the South Boston waterfront has become apparent. In the summer the throngs of pleasure seekers at the beaches have incrcased more rapidly than accommodations could be provided. The crowds which could not be accommodated at the Strandway made use of the meager approaches to Castle Island. The constant use of the temporary wooden causeway now falling to decay has shown that the public is willing to walk a long distance and to experience discomfort in order to enjoy the breezes and the ocean and harbor views from the old parade ground and from the terraces and outer works of Castle Island. Fort Independence itself draws an increasing number of visitors each year.

As the temporary causeway will soon become impassable, the Park Commissioners have made plans to replace it by a tree-shaded roadway and a water-side promenade placed on the earth fill already provided adjacent to the wooden structure. It is proposed to carry these approaches to the high ground near the outer battery at the western end of the fort, and thence between the officers' ancient quarters and the fort, to the southern extremity of the parade ground beyond the grove of great elms. In consideration of the cxtensive use made by the public of the comparatively narrow strips of grass on the north and east terraces of the fort, automobiles will not be permitted to make a complete circuit of the island. Motorists will be accommodated, however, by an ample roadway, by a parking space on the high ground overlooking Pleasure Bay, Dorchester Bay, and the Harbor, and by the large motor concourse, already mentioned, on the parade ground at the point of the island overlooking all the waters to the east, south and west. The plan (Plate XVI) and the bird's-eye view (Plate XV) show the proposed general plan and its relation to City Point, the Strandway and Columbus Park. Industrial development of the flats north of the causeway upon filled ground is shortly to take place. The plan indicates a portion of the general layout which the state proposes for the approach to this industrial area, and the relation of this development to the roadways and the promenade of the causeway. The construction of the causeway would create opportunities for another large bathing beach within easy reach of the City trolley lines and in proximity to the main motor routes. 


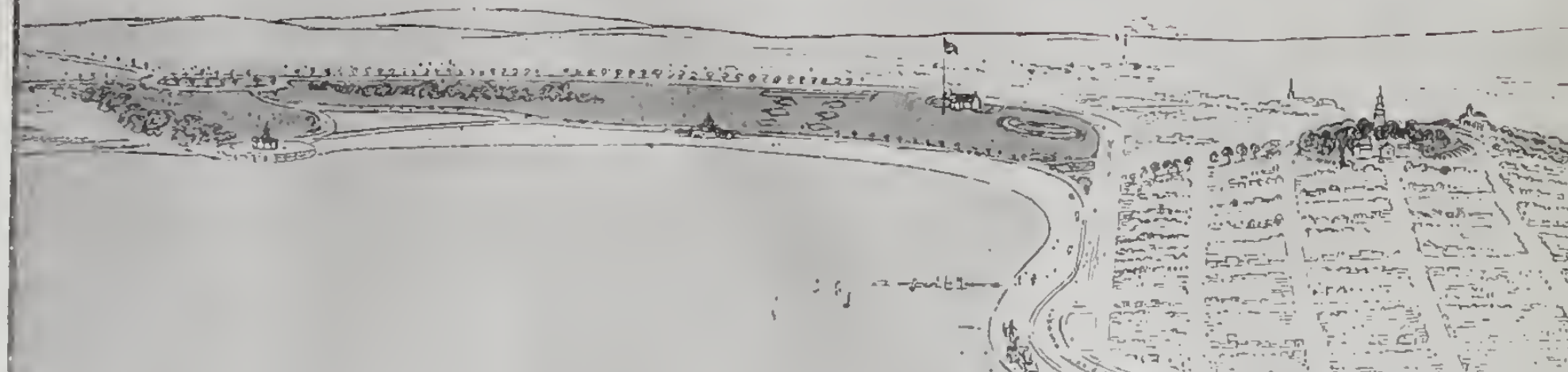





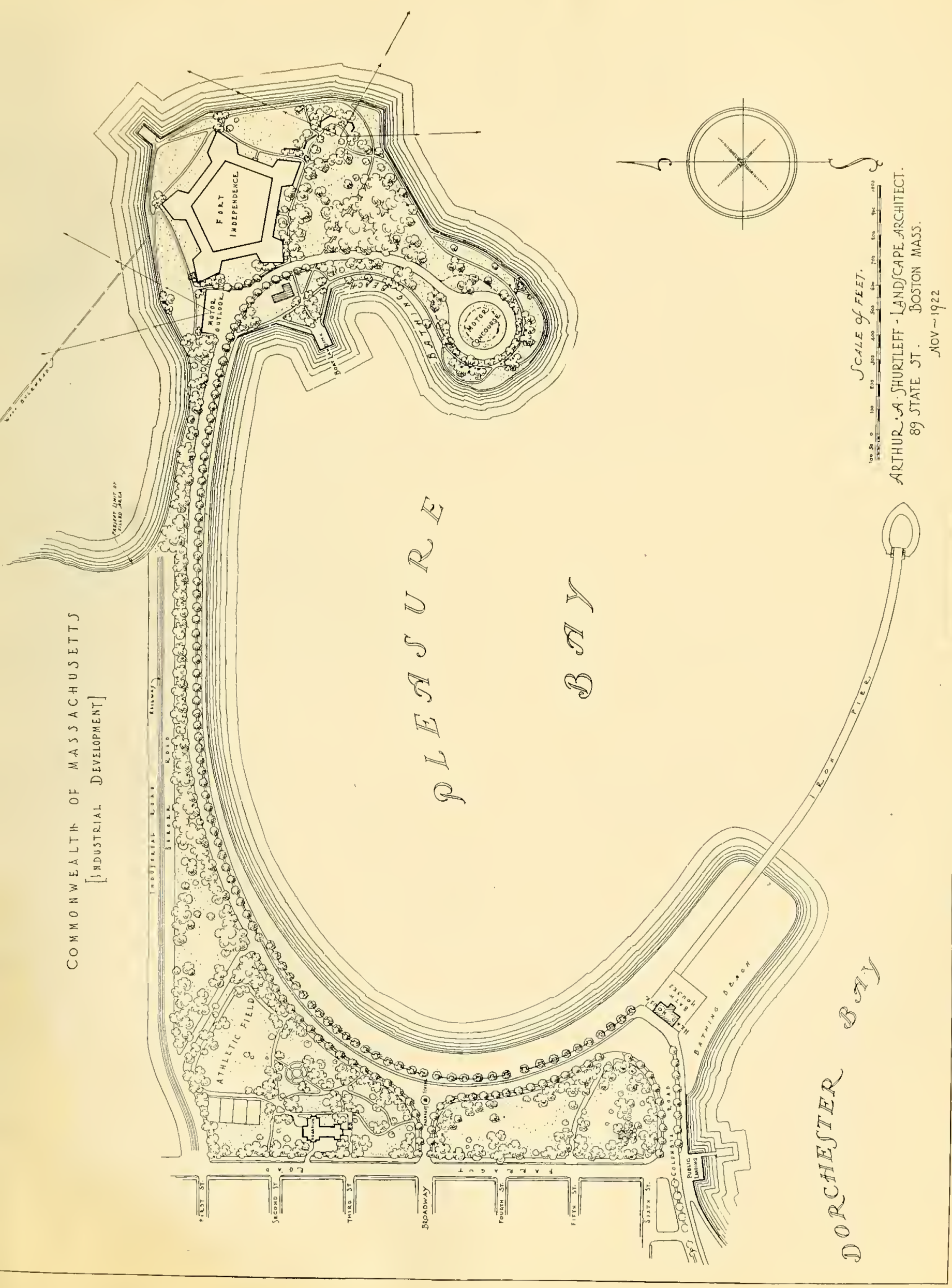




\section{LIST OF PARKS, PLAYGROUNDS, PUBliC SQUARES, ETC., AND LOCATIONS.}

[Playgrounds starred are named for soldiers killed in the World War.]

No. Present Name.

Mary Hemenway Playground.

121

Fred C. W. Olson Square *...

Andrew Henry Square*

Algonquin Square.

4 Stanley A. Ringer Playgrcund *.

5 Alvah Kittredge Park.........

6 Arborway.

7 Arnold Arboretum.

8 James L. Cronin Playground *.

9 Belmont Square.

10 Bennett Playground. Beach.

Chestnut Hill Park

City Square.

Columbia Road

Willian E. Carter Pliyground *

Columbus Park.

Columbus Square..

Commonwealth Arenue.

Concord Square

Copley Square
Previously KNoWn As

Adims Street Playground

Public Square

Adans Square.

Algonquin Square.

Allston Playground

Alvah Kittredge Park

Arborway.

Arnold Arboretum

Ashmont Playground.

Belmont Square. .

Bennett Playground.

Berners square.

Berwick Park

Billings Field Playground.

Blackistone Square

Boston Common..

Brighton Square

Bromley Park

Camp Meigs..... .

Carolina Avenue Playground.

Carruth Square. .

Castle Island...

Cedar Square

Centervale Park.

Central Square.

Centre Square.

Ceylon Street.

Charlesbank

Charlestown Heights and Dewey Bench.

Copp's Hill Terraees

Colunbia Road.

Columbus Avenue Playground

Columbus Park. .

Commonwealth Arenue

Concord Square

Copley Square.

Copp's Hill Terraces.

LOCATION.

District.

Columbus Square
532 Adams Street.

Junction, Adams and Codman streets

Junetion, Adams and Ciranite Streets.

Algonquin and Bradlee Streets.

Allston Street. .

Highland Street and Highland Avenue.

Prince Street to Franklin Park. .

South, Centre and Walter Streets.

Brent Street, near Talbot Avenue.

Webster, Sumner and Lamson Streets

Charles Street Place.

Longriood Avenue, Bellevue and Plymouth Streets.

Columbus Avenue and New York, New

Haven \& Hartford Railroad.

La Grange and Bellevue Streets.

Washington Street, between West Brooklime and West Newton Streets.

Tremont Street to Charles Street; Beacon Street to Boylston Street.

Chestnut Hill Avenue and Academy Hill Road.

Albert Street to Bickford Street......

Readville.

Between Carolina Avenue and Child Street.

South Fairview and Roberts Streets....

Boston Harbor.

Between Juniper and Thornton Streets. Roxbury.

Upland Avenue and Bournside Street,

Meridian and Border Streets. .

Centre and Perkins Streets.

Ceylon, near Magnolia Street.

Charles Street...

Bunker Hill and Medford Streets.

Beaeon Street and Commonwealth Avenue.

Head of Bow and Main Streets

From Franklin Park to Marine Park. .

Dorchester.

Dorchester.

Dorchester.

Dorchester.

Brighton.

Roxbury.

Jamaica Plain.

Jamaica Plain.

Dorchester.

East Boston.

Charlestown

Roxbury.

City:

West Roxbury.

City.

City.

Brighton.

Roxbury.

Hyde Park.

Jamaica Plain.

West Roxbury.

Boston.

Dorchester.

East Boston.

Jamaica Plain.

Dorchester.

City.

Charlestown.

Brighto'

Charlestown.

(Doreheste:

South Bos 6.l.

Columbus Avenue and Comden Street.

Roxburv.

South Doston.

At haad of Dolchester Bay.

Cit,

City:

Brigl a.

Arlington Street to Newton Iine.

City. Avenue.

Between Huntington Avenue, Boylston City. and Dartmouth Streets.

Commercial and Charles Streets
City. 


No. I'TESHNT NAMH.

52 Dorchester Park

72 Drohan Square. .

69 Laton Square...

157 lichard Everett Squire

30 Lim Hill Park.

155 Essex Square

43 Finetory Hill Playground.

so J. M. and J. J. Sullivan Playground,*

139 Back Bay Fens.

131 Fern Square.

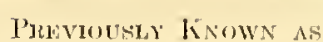

1)oreliester Park

Drolıan Square. .

Liton Square.....

Edward Everett Squirc

Elm Hill Park

Essex Square.

Factory Hill Playground.

Fellows Street Playground.

Back Bay Fens. .

Fern Square

M Street Plityground

Public Ground, Florida Street

Forest Hills Playground.

Fort Hill Square.

Francis Street Circle. .

Franklin Field

Franklin Park

Franklin Square

Christopher Gibson Playground Greenwood Square......... .

Harold Square

Hayes Square.

General Heath Square.

Heath Street.............

Highland Park. . . . .

Horatio Harris Park.

Independence Square

Jackson Square. .

John Winthrop Playground.

Lincoln Square...

Linwood Park

Longwood Palk

Madison Park.

Magnolia Street

Mlarcella Street Playground.

Mlarine Park........

Massachusetts Avenue Malls

City Storage Lot. . .

Maverick Square.

Dorchester Square. .

Milton Squne.

\section{IOCATION}

DISTIUC".

Dorchester Avenue and Richmond Stree1.

Erlison Green.........

Dorchester. Dorchestrer.

Ardums and bowdoin Streets

Dorchester.

Junetion, Columbia Road and Massachusetts Avenue.

Off 5.50 Warren street

Essex and Iyndeboro Strects.

Roxbury.

Town Street

Humeman Street

Beaeon Street to Brookline Avenue.

Between Franklin and Fern Streets....

First Street at M Street.

Fing Street to Ashmont Street.

Washington Street and Firth Road.

Oliver and High Streets.

Chrirlestown.

Hyde Park.

lioxbury.

City.

Brighton.

South Boston

Dorchester.

Roslindale.

City.

Junction Ifuntington Avenue, Tremont and Francis Streets.

Blue Hill and Talbot Avenues.

Roxbury.

Dorchester.

Seaver Street to Morton Street; Blue Hill Ayenue to Forest Hills Street.

Washington Street, between Brookline and Fast Newton Streets.

Dorchester Ayenue and Bourneside Street.

Junction Greenwood Street and Central Avenue.

Crawford, Abbotsford and Harold Streets.

Bumker Hill and Vine Streets... . . . . . . .

Old Heath, New Heath and Parker Streets.

Heath and Day Streets.............

Fort Avenue and Beech Glen Street.

Walnut Avenue, Monroe Street to Townsend Sireet.

Broudway, $M$ and $N$ Streets

Chestnut Hill Avenue, Union and Minship Streets.

Dacia and Danube Streets.

Emerson, Fourth and M Streets

Centre and Linwood Streets.

Park and Austin Streets.

Sterling, Marble and Westminster Streets.

Magnolia Street.

Marcella and Ilighlind Streets. .

Farragut Road, City Point. .

Four sections, between Columbus Avenue and Albany Street.

Massaehusetts Avenue, adjoining New York, New Haven and Hartford Railroad.

Sumner and Maverick Streets.

Meeting House Hill.

Mlilton Avenue and Highland Street.... Hyde Park.
East Boston.

Dol'chestel.

\section{Charlestown.}

Roxbury.

Poxbury.

Rosbury.

Roxbury

South Boston.

Brighton.

Dorehester.

South Boston.

Roxbuly.

Roxbury.

Roxbury.

Dorchester.

Roxbury.

South Boston.

City.

Roxbury. 


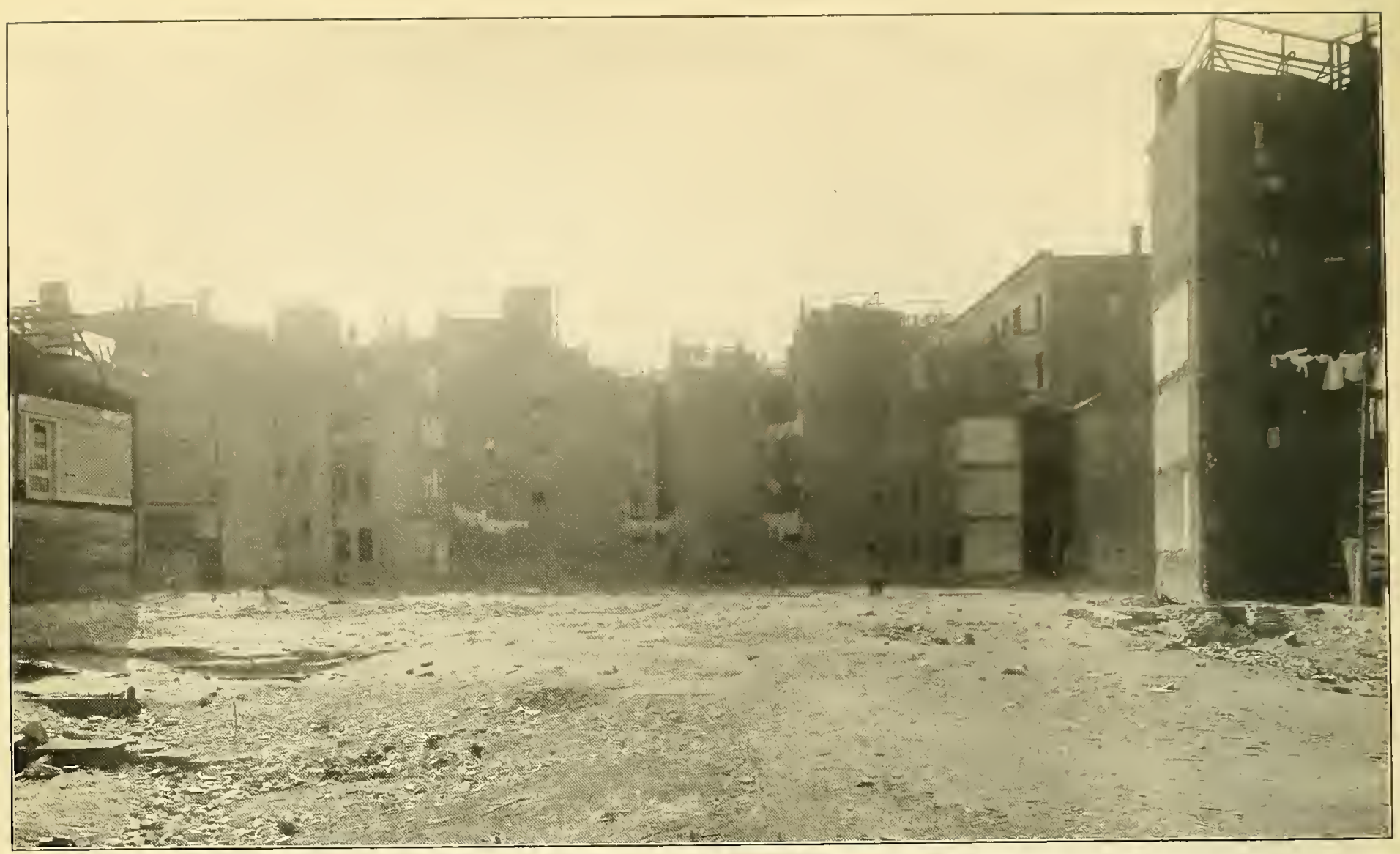

MORTON STREET PLAYGROUND AFTER THE REMOVAL OF BULLDINGS BUT PREVIOUS TO THE CONSTRUCTION OF PLAYGROUND.

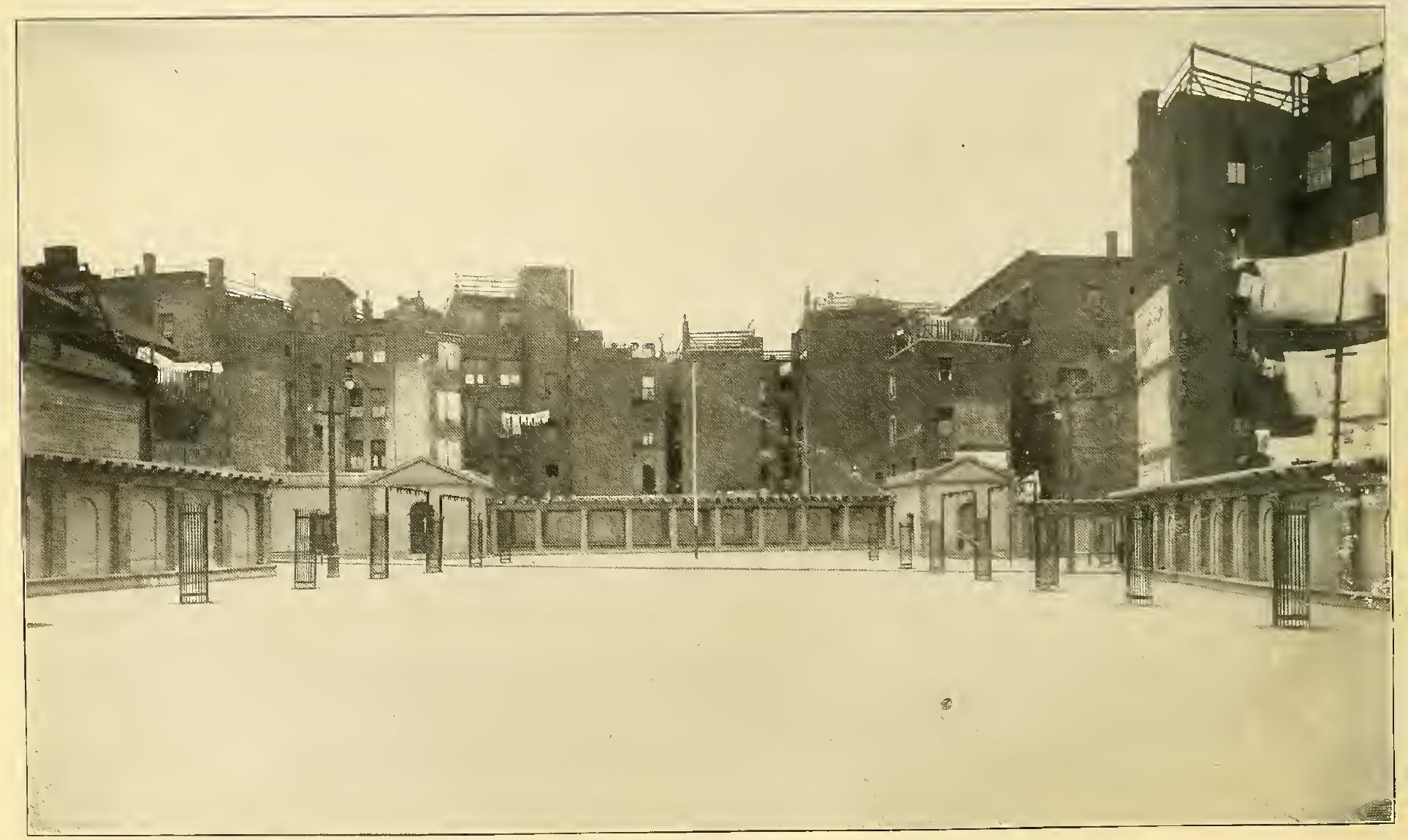




\begin{tabular}{|c|c|c|c|c|}
\hline No. & l'IZESGNT NAME. & Priviously líown as & I JOYA'ION. & JistIRE" \\
\hline 66 & Mt. Bowdoin Green.... & MIt. Bowdoin Green... . & Summit of Mt. Bowdoin. . . . . . . . . . . & Dorchester. \\
\hline 67 & Ronan Park. & MIt. Ida Playground. . & Bowdoin and Percival Streets.......... & Doreluster. \\
\hline 106 & Vincent Cutillo Park*.. & Morton Street Playground... & Morton and Stillman Streets........... & City. \\
\hline 17 & Jolın I. Hollind Playground * . . . . . & Mozart and Bolster Streets Playground, & Mozart and Bolster Streets........... & Roxbury. \\
\hline 113 & William J. Barry Playground *. & Nyrstic Playground. ............... & Chelsea and Medford Streets....... & Charlestown. \\
\hline 56 & William H. Garvey Playground * . . . & Neponset Playground.............. & $\begin{array}{l}\text { Neponset Avenue, opposite Chickataw- } \\
\text { but Strect. }\end{array}$ & Dol"chestel: \\
\hline 51 & George H. Walker Playground **. & Norfolk Strect Playground........... & Norfolk Street, opposite Evelyn Street. . & Mattapan. \\
\hline 130 & William F. Smith Playground *. & North Brighton Playground. . . . . . . . . & Western Avenue, near North Harvard & Brighton. \\
\hline 140 & Oak Square. . & Oak Square............ & Washington and Faneuil Streets........ & Brighton. \\
\hline 18 & Oakview Terrace. & Oakview Terrace. . & Off Centre Street near Fourth Street... & Jamaica Plain. \\
\hline 156 & Olmsted Park. & Olmsted Park... & $\begin{array}{l}\text { Huntington Avenue, Roxbury, to Prinec } \\
\text { Street. Jamaica Plain. }\end{array}$ & Jamaica Plain. \\
\hline 79 & Ol'chard Park. & Orehard Park. & $\begin{array}{l}\text { Chadwick, Orcliard Park and Yeoman } \\
\text { Streets. }\end{array}$ & Roxbury. \\
\hline 129 & Orient Heights Playground. & Orient Heights Playground.. & Saratoga and Boardman Streets....... & East Boston. \\
\hline 126 & Paris Street Playground. & Paris Street Playground.. & Paris Street............. & East Boston. \\
\hline 104 & Abraham Lineolu Square. & Abraham Lineoln Square. & $\begin{array}{l}\text { Junctiou Columbus Avenue, Eliot Street } \\
\text { and Broadway. }\end{array}$ & City. \\
\hline 53 & Peabody Square. . & Peabody Square... & Ashmont Street and Dorchester Avenue, & Dorchester. \\
\hline 132 & Portsmouth Street Playground. & Portsmouth Street Playground....... & Portsmouth Street. . . . . . . . . . . . . & Brighton. \\
\hline 107 & Prince Street Playground... & Prince Street Playground... . & North Bennet and Prince Streets...... & City. \\
\hline 120 & Prescott Square. . & Prescott Square.... & Trenton, Eagle and Prescott Streets.... . & East Boston. \\
\hline 105 & Public Garden. . & Public Garden. . & $\begin{array}{l}\text { Charles Street to Arlington Street; Bea- } \\
\text { con Street to Boylston Street. }\end{array}$ & City. \\
\hline 119 & Putnam Square. & Putnam Square. . & Putnam, White and Trenton Streets... & East Boston. \\
\hline 90 & Lester J. Rotch Playground*. & Randolph Street Playground... & Albany and Rindolph Streets......... & City. \\
\hline 75 & Richardson Square. & Richardson Square... & Between Pond and Cottage Streets.... & Dor chester. \\
\hline 65 & Ripley Playground. & Ripley Playground... & Ripley Road, near Harvard Street... & Dor chester. \\
\hline 158 & Riverway........... & Riverway ...... & Brookline Avenue to Huntington Avenue, & Roxbury. \\
\hline 136 & Rogers Park. & Rogers Park........... & Lake and Foster Streets........... & Blighton. \\
\hline 37 & Irving W. Adams Park * . . . . & Roslindale Park........ & Junetion, Washington and South Streets, & Roslindale. \\
\hline 39 & Fallon Field *... & Roslindale Playground............. & South and Roberts Streets... & Roslindale. \\
\hline $1 ! 4$ & Frederick D. Emmons Playground *. & Rutherford Avenue Playground. & Rutherford Avenuc... & Charlestown. \\
\hline 150 & Rutland Square.... & Rutland Square..... & Between Tremont Street and Columbus & City. \\
\hline 71 & Savin Hill Park. & Savin Hill Park. & Grampian Way........... & Dorchester. \\
\hline 123 & Artluur F. MeLean Playground * . . . & Mothers' Rest, Saratoga Street.... & Saratoga and Bennington Streets..... & East Boston. \\
\hline 70 & McConnell Park*. & Savin Hill Playground. & Springdale and Denny Streets... & Dorchester. \\
\hline 160 & Public Ground, Seaver Street. . . . . . & Public Ground, Seaver Street. . . . & Corner Blue Hill Avenue and Seaver & Roxbury. \\
\hline 42 & Smith's Pond Playground. . & Snith's Pond Playground. & Stony Brook Reservation, near Brainard & Hyde Park. \\
\hline 34 & Soldier's' Monument Lot. . . . . . . . . . & Soldiers' Monument Lot. . & South and Centre Streets............ & Jamaiea Plain. \\
\hline 55 & Spaulding Square. & Spaulding Square... & Junction, Freeport Street and Neponset & Dor chester. \\
\hline 83 & St. Steplien Square. & St. Stephen Square. . . . . . . . . . . . . & Corner St. Stephen and Batavia Streets, & City. \\
\hline 142 & Strandway. . & Strandway. . & From Columbus Park to Marine Park, & South Boston. \\
\hline 117 & Sullivan Square. & Sullivan Square. . & $\begin{array}{l}\text { Main, Cambridge, Seaver and Gardnel } \\
\text { Streets. }\end{array}$ & Charlestown. \\
\hline
\end{tabular}




\begin{tabular}{|c|c|c|c|c|}
\hline No. & Primgint Name. & PREVIOUSLY liNoWN as & LOCATHOA. & District. \\
\hline 96 & Thomas Park. ...... & Thomas Park. & J'elegripl Hill..... & South Boston. \\
\hline 63 & Tremlett Square. & Tremlett Square................ & $\begin{array}{l}\text { Tremlett Street, between Hooper inrl } \\
\text { Waldeck Streets. }\end{array}$ & Dorchester. \\
\hline 92 & Tyler Strect Pliyground. . & Tyler Street Playground............ & Tyler Street, South End............. & City. \\
\hline SS & Union Pork. & Union Park....... & $\begin{array}{l}\text { Between Tremont Street and Shawmut } \\
\text { Avenue. }\end{array}$ & City. \\
\hline 48 & Horace Camphell Woodworth Sq., & Vose Square. & $\begin{array}{l}\text { Beacon Street and Metropolitan } \\
\text { Avenue. }\end{array}$ & Hyde Park. \\
\hline 163 & Francis Parkman Playground.. & Wachusett Street Playground. . & Waehusett Street............... & Forest Hills. \\
\hline 28 & Walnut Park.. & Walnut Park. & $\begin{array}{l}\text { Between Washington Street and Walnut } \\
\text { Avenue. }\end{array}$ & Roxbury. \\
\hline 89 & Waltham Square. & Waltham Square.... & $\begin{array}{l}\text { Harrison Avenue, opposite Union Park } \\
\text { Street. }\end{array}$ & City. \\
\hline 161 & Warren Square... & Warren Square..... & Warren, St. James and Regent Streets, & City: \\
\hline 26 & Washington Park. & Washington Park................ & Dale and Bainbridge Śtreets........... & Roxbury. \\
\hline 14 & Mission Hill Playground. . & Ward 19 Playground. & Tremont and Smith Streets...... & Roxbury. \\
\hline 49 & Webster Square...... & Webster Square. . . . . . . . . . . . . . . . & Junetion, Webster and Central Avenues, & Hÿde Park. \\
\hline 62 & Wellesley Park... & Wellesley Park.................... & Wellesley Park Street............... & Dorchester. \\
\hline 95 & Matthew J. Sweeney Playground *.. & West Fifth Street Playground........ & West Fifth Street, corner B Street.... & South Boston \\
\hline 44 & Willians Squarc. . & Williams Square......... & Williams Avenue and Prospect Street.... & Hyde Park. \\
\hline 78 & William Eustis Playground. & William Eustis Playgı ound. . . . . . . . . & Norfolk Avenue and Proctor Street.... . & Roxbury. \\
\hline 111 & Winthrop Square. & Winthlop Square........ & Winthrop, Cömmon and Adams Streets, & Charlestown. \\
\hline 45 & Wolcott Squar'c. . . . . . . . & Wolcott Square. . . & $\begin{array}{l}\text { Iyde Park Avenue, Milton and Prescott } \\
\text { Streets. }\end{array}$ & \\
\hline 24 & Wortd War Memorial Parli. & Wood Island Park. & On eastern waterfront. . . . . . . . . . . & Fast Boston. \\
\hline$\$ 5$ & Worcester Square. . & Wor cester Square... & $\begin{array}{l}\text { Between Washington Street and Harri- } \\
\text { son Avenue. }\end{array}$ & City. \\
\hline 109 & North End Beach. . . . . . . . . . . . & North End Beach.......... & Commercial Street................ & City. \\
\hline 19 & Paul Gorc Strect Playground . . . . . & Paul Gore Street Playground. & Paul Gore Strcet............. & Jamaica Plair \\
\hline 133 & Public Land, Brighton. . . . & Public Land, Brighton. . . . & Lincoln and Cambridge Streets......... & Brighton. \\
\hline 73 & Public Land, Dor chester. & Public Land, Dorchester . . . . . & $\begin{array}{l}\text { Smelt Brook Creek, Vietory Road and } \\
\text { Park Street. }\end{array}$ & Dol cliester. \\
\hline 162 & Edward M. Cunningham Park* . & Sparhawk Square... & $\begin{array}{l}\text { Cambridge, Murdock and Sparhawk } \\
\text { Streets. }\end{array}$ & Brighton. \\
\hline 64 & William B. Corbett Park* . & Mothers' Rest Park, Dorchester Centre, & Washington and Claybourne Streets..... & Dorchester. \\
\hline 74 & City Nursery Grounds. & City Nursery Grounds. . . . . . . . . & $\begin{array}{l}\text { Massachusetts Avenue and East Cottage } \\
\text { Street. }\end{array}$ & Dorchester. \\
\hline 122 & Condor Street Playground. . & Condor Street Playground. . . . . . . . . . & Condor and Glendon Streets.......... & East Boston. \\
\hline 31 & Tree Area, Elm Hill Avenue. & Tree Area, Elm Hill Arenue. . . . . . . . . & $\begin{array}{l}\text { Elm Hill Avcnue, between Seaver and } \\
\text { Schuvler Streets. }\end{array}$ & Roxbury. \\
\hline 118 & Francis G. Kane Square* . & Francis G. Kane Square... . . . & $\begin{array}{l}\text { Junetion, Bowdoin, Winter and Han- } \\
\text { cock Streets. }\end{array}$ & Dorehester. \\
\hline 100 & City Hall Grounds........ & & School Street................. & \\
\hline 94 & Tenean Beach Playground.. & Tenean Beaeh Playglound... & 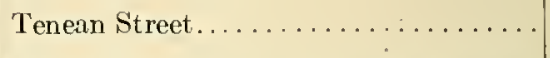 & Dor" \\
\hline 58 & Cherry Street Playground & South Fnd Playground....... & $\begin{array}{l}\text { Cherry and Lueas Streets, between } \\
\text { Shawmut Avenue and IIashington } \\
\text { Street. }\end{array}$ & City. \\
\hline 15 & John A. Doherty Playground *. & Part of Christopher Gilsson Playground, & Dorchester Avenue and Park Street.... & Dorchest \\
\hline 101 & Trinity Triangle. & Trinity Triangle. & $\begin{array}{l}\text { Huntington Avenue, Trinity Plaee and } \\
\text { St. James Avenue. }\end{array}$ & $\mathrm{Ci}^{+*-}$ \\
\hline 102 & Town Mecting Square Site. & Town Meeting Square Site. . . . . . . . & Cottage, Pleasant and Pond Streets.... & Dor \\
\hline 59 & Malloeh's Wharf Grounds. & Malloch's WTherf Grounds........ & Freeport Street................. & $\perp$ \\
\hline 93 & West Third Strect Playground... . & & Corner D and Third Streets....... & Sou' \\
\hline 116 & Charlestown Playground......... & & Alford Street.......... & Che \\
\hline 144 & Arborway Entrance to Franklin Park, & & & \\
\hline 145 & West Roxbury Parkway. & & & \\
\hline
\end{tabular}




\section{INDEX TO SUBJECTS.}

The Boston Park System

Boston Common

The Fens Playground

Proposed Fens Improvement Opposite the Art Museum

The Zoo

The Rose Garden
Page

3

5

10

10

13

16

18
Christopher Gibson and John A. Doherty Play-

Page grounds

The Christopher J. Lee Playground

Columbus Park

Public Cemeteries.

\section{INDEX TO ILLUSTRATIONS.}

Plate I.- Map of Metropolitan Distriet .

Plate II.- Map of the City of Boston Showing Loeation of All Open Spaces . Boston Common.- Liberty Mall, Looking Toward State House

Plate III.- General View of Boston Common

Boston Common.- Steps at Head of Liberty Mall

Plate IV.- General Plan, Showing Development of Boston Common

Commonwealth Avenue Before Elimination of Curves .

Commonwealth Avenue After Elimination of Curves

Plate V.- Birdseye View of Proposed Development in the Fens

Plate VI.- Proposed Arrangement of Fens Opposite Art Museum

Present Condition of Fens Opposite Art Museum

Stream and Bridge in Muddy Brook Parkway

Plate VII.- Birdseye View of Proposed Development in the Fens

Commonwealth Avenue Before Improvements

Commonwealth Avenue After Improvements

Plate VIII. - General Plan for Zoological Garden

Franklin Park. - Herbaeeous Gardens

Plate IX.- General View of Rose Garden

Plate X.- Birdseye View of Rose Garden

Franklin Park - General View of Large Play Field

Franklin Park.- Toboggan Slide

Plate XI.- General Plan of Christopher Gibson Playground

Plate XII.-General Plan of Christopher Lee Playground .

View of Circle at Entrance to Columbus Park

Strandway Beach at South Boston.

Plate XIII.- General Plan for Columbus Park

Plate XIV.- Birdseye View of Columbus Park

Outdoor Entertainment at Franklin Park

Snow Scene in Park System

Plate XV. - Birdseye View of Proposed Development of Castle Island

Plate XTI.- Proposed Plan for Development of Pleasure Bay .

Merton Street Playground Before Construction

Morton Street Playground After Construction

Bathing Beach at South Boston

Plate XVII.- General Plan of Mt. Hope Cemetery
PAGE

Between pages 2 and 3

Between pages 4 and 5

Between pages 8 and 9

Between pages 11 and 15

Between pages 16 and 17

Between pages 18 and 19

Between pages 18 and 19

Between pages 26 and 27 Between pages 26 and 27

Between pages 28 and 29 


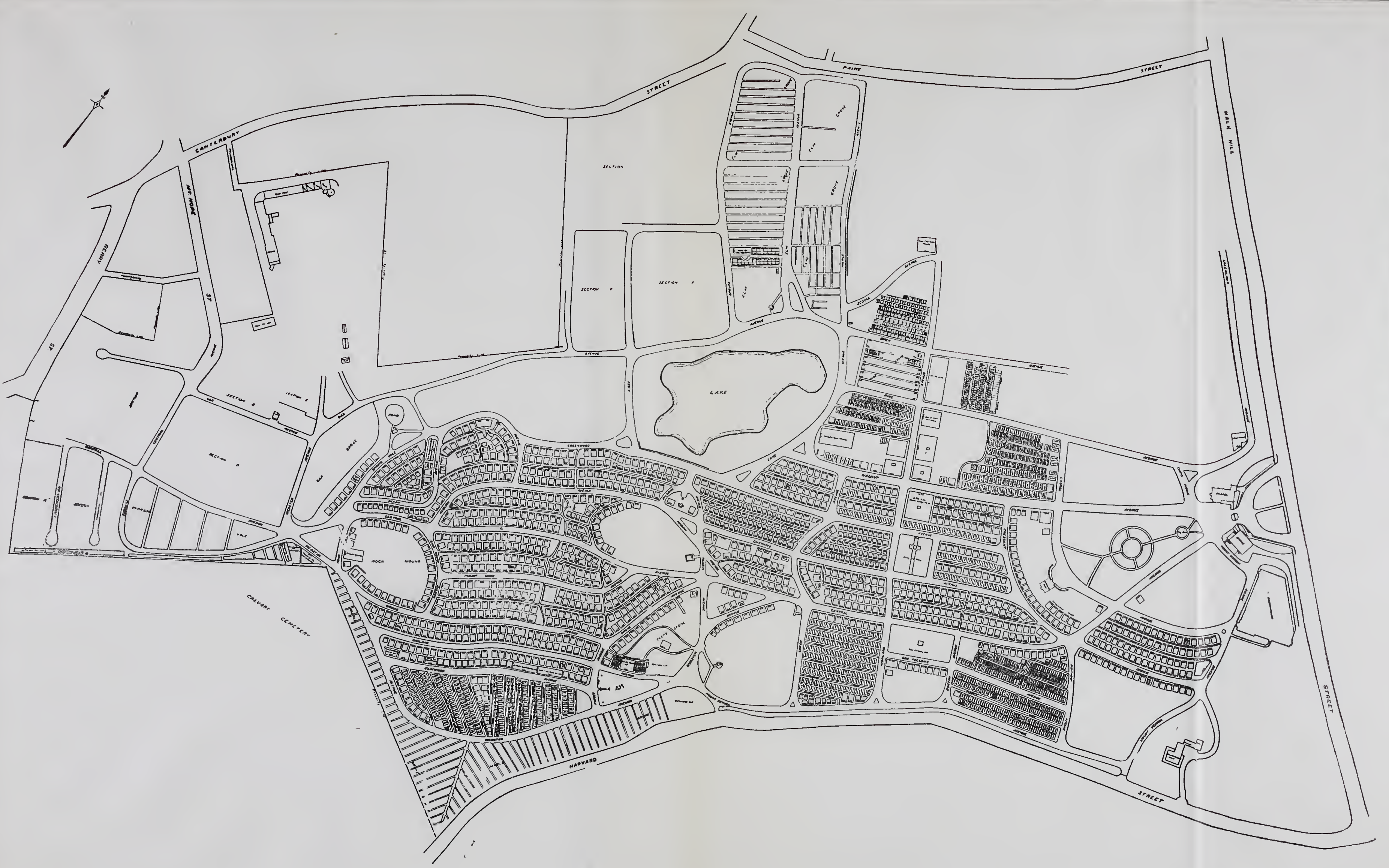

PLATE XVII,-GENERAL PLAN OF MT. HOPE CEMETERY SHOWING SURROUNDING STREETS AND THE GENERAL SCHEME OF INTERIOR ROADS, PATHS, AND ARRANGEMENT OF LOTS, I922. 


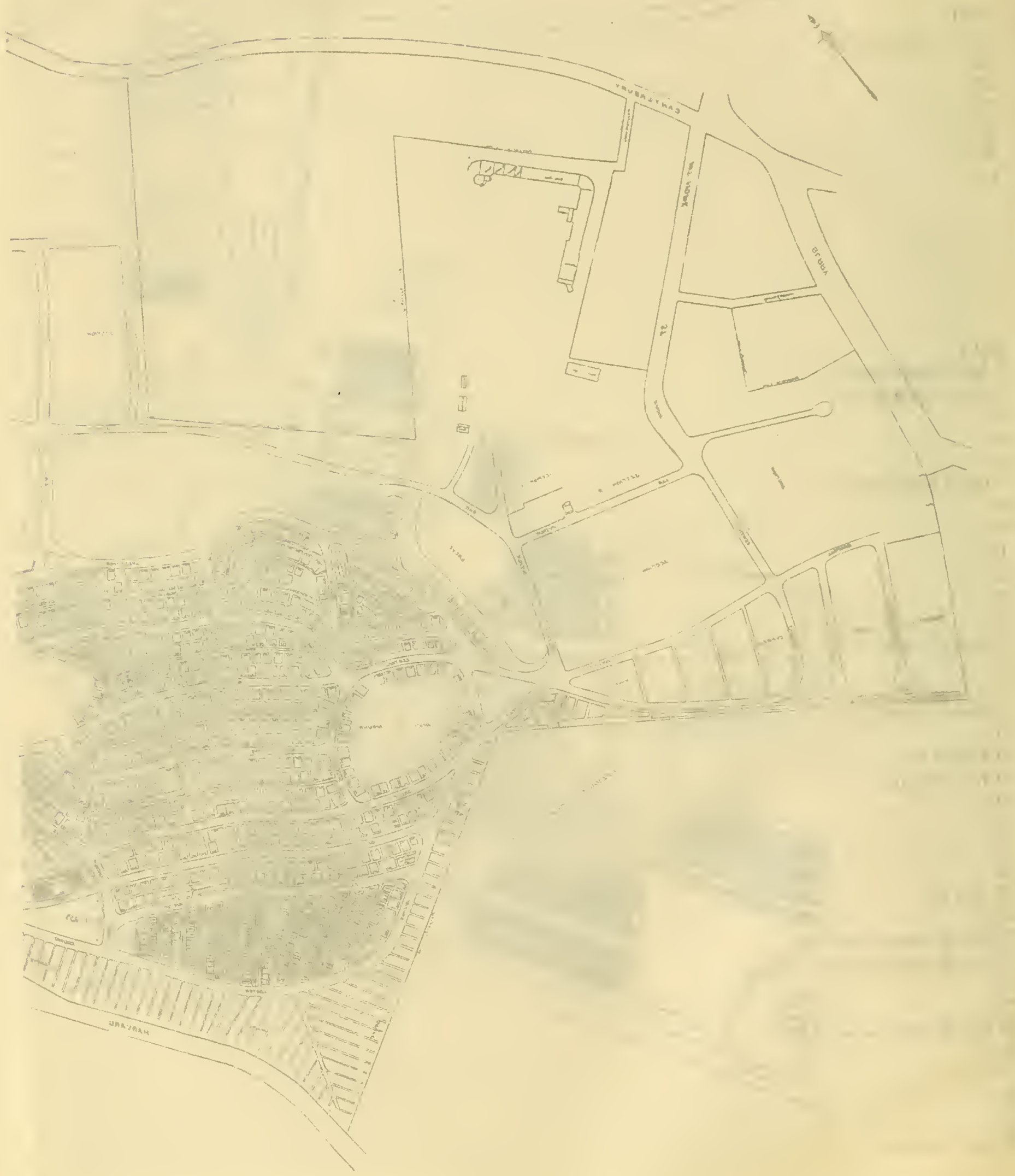





$3,511 \div 0$ 


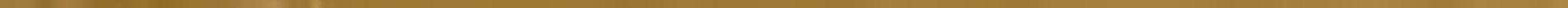


CITY OF BOSTON-PRINTING DEPARTMENT 



